\title{
ROLLOVER RISK: IDEATING A U.S. DEBT DEFAULT
}

\author{
STEVEN L. SCHWARCZ*
}

\begin{abstract}
This Article examines how a U.S. debt default might occur, how it could be avoided, its potential consequences if not avoided, and how those consequences could be mitigated. The most realistic default would result from rollover risk: the risk that the government will be temporarily unable to borrow sufficient funds to repay its maturing debt. The United States, like most governments, routinely finances itself through short-term debt, which is less expensive than long-term debt. But this cost-saving does not come free of charge: it increases the threat of default. A U.S. debt default-even a mere "technical" default such as temporarily missing an interest or principal payment-would have severe economic and systemic consequences both domestically and worldwide. Such a default would also raise a host of legal issues, including questions of first impression under the Fourteenth Amendment to the Constitution.
\end{abstract}

\section{INTRODUCTION}

Although many would agree that "an eventual default [by the United States government] on [its] Treasury debt [is] a conceivable, although unlikely, outcome," concern is growing. ${ }^{1}$ When the U.S. Secretary of the Treasury met recently with a group of Chinese students, they laughed contemptuously at the

(C) 2014, Steven L. Schwarcz. All rights reserved.

* Stanley A. Star Professor of Law \& Business, Duke University School of Law, and Founding Director, Duke Global Capital Markets Center; schwarcz@law.duke.edu. This Article expands and develops the author's presentation at the University of Iowa College of Law April 13, 2013 conference, "Fiscal Reform, Monetization, or Default: How Will the United States Solve the Problem of its National Debt?” The author thanks participants in that conference and also Donald S. Bernstein, Elisabeth de Fontenay, Deborah Lucas, Julie Maupin, Robert T. Miller, Charles W. Mooney, Jr., and participants at a lecture at Stanford Law School for their valuable comments and Paulina Stanfel and Joan Kerecz for excellent research assistance.

${ }^{1}$ Deborah Lucas, The Federal Debt: Assessing the Capacity to Pay, in Is U.S. GovERNMENT DEBT DIFFERENT? 101, 101 (Franklin Allen et al. eds., 2012) (arguing "that current fiscal policy is on an unsustainable trajectory”); see Satyajit Das, The Main Event-The U.S. Debt Crisis, EconoMONITOR (Nov. 20, 2011), http://www.economonitor.com/blog/2011/11/the-main-event-the-u-sdebt-crisis/, archived at http://perma.cc/0Zd5nPT3GwZ (noting that "[n]on-American observers view the debt ceiling debate with morbid fascination and increasing concern”). 
assertion that U.S. government bonds are "safe" investments. ${ }^{2}$ The expanding international market in credit-default swaps on U.S. debt echoes this concern. ${ }^{3}$

Whatever might be the likelihood of a U.S. debt default, its harm could be devastating. ${ }^{4}$ Furthermore, as this Article explains, certain types of U.S. debt defaults are actually quite realistic. ${ }^{5}$ It is therefore important to think through how a U.S. debt default might occur, how it could be avoided, its potential consequences if it is not avoided, and how those consequences could be mitigated.

Part I of this Article examines how the United States might default on its debt, differentiating defaults caused by insolvency from temporary defaults caused by illiquidity. ${ }^{6}$ The latter, which are potentiated by rollover risk, ${ }^{7}$ are not only plausible but have occurred in the past. ${ }^{8}$ Moreover, the ongoing controversy over the federal debt ceiling and the rise of the shadow-banking system make these types of defaults even more likely today. ${ }^{9}$

Part II examines how a U.S. debt default could be avoided, discussing steps-such as monetizing its debt and printing money to pay maturing debt - that the government can take to facilitate debt repayment. ${ }^{10}$ Part II also examines the limits on the government's ability to avoid defaulting. ${ }^{11}$

Part III of this Article analyzes the consequences of a U.S. debt default. ${ }^{12}$ Any such default, even one that is temporary, would have severe economic and systemic consequences, significantly raising the cost of borrowing

${ }^{2}$ Das, supra note 1.

${ }^{3}$ See Richard Squire, A Market for End-of-the-World Insurance? Credit Default Swaps on US Government Debt, in Is U.S. GOVERNMENT DEBT DIFFERENT?, supra note 1, at 69, 71 (explaining that sovereign borrowers represent a large portion of reference entities in the credit-default swaps market). Credit-default swaps ("CDS") are bets on the likelihood that a reference entity-in this case the U.S. government-will default on its debt. Id. at 72-73.

${ }^{4}$ See infra notes 111-194 and accompanying text (discussing the potential legal and economic consequences of a U.S. debt default).

${ }^{5}$ See infra notes $16-59$ and accompanying text (explaining how rollover risk increases the risk of U.S. default on its sovereign debt).

${ }^{6}$ See infra notes $16-59$ and accompanying text.

${ }^{7}$ Rollover risk is the risk that the government will be temporarily unable to borrow sufficient funds to repay its maturing debt. See infra note 21 and accompanying text (explaining rollover risk).

${ }^{8}$ See infra note 48 and accompanying text (explaining that in 1979 the federal debt ceiling prevented the U.S. government from borrowing sufficient funds to repay maturing debt, which resulted in a default).

${ }^{9}$ See infra notes 33-59 and accompanying text (explaining how rollover risk applies specifically to U.S. sovereign debt).

${ }^{10}$ See infra notes $60-110$ and accompanying text.

${ }^{11}$ See infra notes 91-110 and accompanying text (explaining how the magnitude of the problem could make it difficult to avoid a U.S. debt default).

${ }^{12}$ See infra notes 111-194 and accompanying text. 
and causing securities markets to plummet. ${ }^{13}$ A U.S. debt default also would raise a host of legal issues, including questions of first impression under the Fourteenth Amendment of the U.S. Constitution. ${ }^{14}$

Finally, Part IV explores how the negative consequences of a default might be mitigated, potentially through bilateral or unilateral debt restructuring or even through a possible International Monetary Fund (IMF) bailout. ${ }^{15}$ The Article concludes, however, that neither a debt restructuring nor an IMF bailout would likely be successful in effectively mitigating those consequences. It therefore may be more prudent to try to minimize rollover risk ab initio, such as by better managing the issuance of short-term government debt and considering austerity measures that would reasonably limit the government's need to borrow.

\section{How Might the United States Default on Its National DeBt?}

The classic view is that a national debt default, meaning a "hard default" on the debt, which includes non-payment of debt when due, ultimately depends on the country's expenditures exceeding taxes and new borrowings. ${ }^{16}$ That view, however, does not adequately differentiate between insolvency and illiquidity. Insolvency occurs when total liabilities exceed the value of total assets, whereas illiquidity occurs when liquid assets-for example, cash, short-term securities, and other assets readily convertible to cash-are insufficient to pay current liabilities as they become due. ${ }^{17}$ It is possible for a nation to be solvent but illiquid, causing the nation to default on its debt. ${ }^{18}$

\footnotetext{
${ }^{13}$ See infra notes 175-194 and accompanying text (discussing the economic consequences of a default).

${ }^{14}$ See infra notes 114-174 and accompanying text (discussing possible legal consequences of a U.S. default).

${ }^{15}$ See infra notes 195-232 and accompanying text.

${ }^{16}$ See Richard H. Herring, Default and the International Role of the Dollar, in Is U.S. GovERNMENT DEBT DIFFERENT?, supra note 1, at 21, 21 (also using the term "hard default" to describe a distressed exchange offer); Howell E. Jackson, The 2011 Debt Ceiling Impasse Revisited, in Is U.S. GOVERNMENT DEBT DIFFERENT?, supra note 1, at 55, 58-59.

${ }^{17}$ Sergei A. DAVydenKo, Insolvency, Illiquidity, AND tHe Risk of Default 1 (2012). Illiquidity might reduce solvency by forcing a debtor to sell valuable assets at a loss in order to pay current liabilities. Douglas W. Diamond \& Raghuram G. Rajan, Liquidity Shortages and Banking Crises 3 (Nat'l Bureau of Econ. Research, Working Paper No. 8937, 2002), available at http://www. nber.org/papers/w8937.pdf?new_window=1, archived at http://perma.cc/0BSqtPQAWJ9.

${ }^{18}$ See Terry Belton et al., The Domino Effect of a US Treasury Technical Default, J.P. MoRGAN 1-2 (Apr. 19, 2011), http://valkayec.files.wordpress.com/2011/04/morgan.pdf, archived at http://perma.cc/0ZNnoaut2AB (explaining the possible effects of a technical default on U.S. debt caused by the failure to raise the debt ceiling).
} 
This Article assumes that the United States is unlikely to become insolvent soon. ${ }^{19}$ Nonetheless, there is a real risk that the United States could become illiquid. ${ }^{20}$ The most likely cause of illiquidity is rollover risk: the government's temporary inability to borrow sufficient funds to repay or refinance its maturing debt. ${ }^{21}$

\section{A. Rollover Risk and Illiquidity}

Rollover risk is not merely theoretical. A former Under Secretary of the Treasury for Domestic Finance recently observed that "[i]f you ask [U.S.] Treasury ... officials responsible for debt management 'What keeps you up at night?' the only candid reply will be: the risk of not being able to roll[]over their debt at the next auction. In practice, debt sustainability is about rollover risk ....,22

This mirrors one of the author's earliest experiences practicing law. New York's Monroe County had short-term revenue-anticipation notes coming due. As it had done many times in the past, the county-which was financially solvent - offered new notes for sale at public auction, intending to use the proceeds to repay the maturing notes. Unfortunately, because of feared contagion from what was then New York City's financial crisis, ${ }^{23}$ nobody showed up to buy the new notes.

Though seemingly less dramatic than insolvency, a U.S. debt default caused by rollover risk could seriously undermine the perception of U.S. gov-

${ }^{19}$ But see Satyajit Das, “We Interrupt Regular Programming to Announce That the United States of America Has Defaulted," ECONOMONITOR (Nov. 11, 2008), http://www.economonitor. com/blog/2008/11/we-interrupt-regular-programming-to-announce-that-the-united-states-of-americahas-defaulted/, archived at http://perma.cc/0u2L9S4KWnN (quoting the head of global investment for South Korea's National Pension Fund, Kwag Dae Hwan, as stating that "[a] big question mark hangs over whether the US can deal with an unprecedented amount of debt. That is unnerving all the investors, including me.”).

${ }^{20}$ See Nouriel Roubini, Liquidity/Rollover Risk on US Assets? A Nightmare Hard Landing Scenario for the US \$ and US Bond Market, ECONOMONITOR (Dec. 21, 2004), http://www.economonitor.com/ nouriel/2004/12/21/liquidityrollover-risk-on-us-assets-a-nightmare-hard-landing-scenario-for-the-usand-the-us-bond-market/, archived at http://perma.cc/0pzwZqEYeHE (explaining that there is a real risk of a liquidity crisis in the United States).

${ }^{21}$ Markus K. Brunnermeier, Deciphering the Liquidity and Credit Crunch 2007-2008, J. ECON. PERSPS., Winter 2009, at 77, 91-92 (discussing rollover risk in the context of the private market). Rollover risk technically also includes the risk that the refinancing cost will be higher than expected. Id. at 79-80.

${ }^{22}$ Peter R. Fisher, Thoughts on Debt Sustainability: Supply and Demand Keynote Remarks, in Is U.S. GOVERnMENT DeBT Different?, supra note 1, at 87, 99. Peter Fisher served in this position in the Department of Treasury from 2001-2003, and is currently the Senior Managing Director of BlackRock, the world's largest asset manager. See id. at x.

${ }^{23}$ See generally E.J. McMahon \& Fred Siegel, Gotham's Fiscal Crisis: Lessons Unlearned, PUB. INT., Winter 2005, at 96 (discussing New York City’s 1975 financial crisis). 
ernment creditworthiness. ${ }^{24}$ That, in turn, could create a devastating feedback loop: the reduced perception of creditworthiness could prevent the nation from borrowing sufficient new money needed to repay future maturing debt - or, at least, increase the cost of that borrowing - thereby further increasing rollover risk and triggering additional defaults and an even larger debt crisis. ${ }^{25}$

Because rollover risk is such a concern, one might ask why governments, including the United States, routinely depend on borrowing new money to repay their maturing debt. The answer is cost: using short-term debt to fund long-term projects is attractive because, if managed to avoid a default, it tends to lower the cost of borrowing. ${ }^{26}$ The interest rate on short-term debt is usually lower than that on long-term debt because, other things being equal, it is easier to assess a borrower's ability to repay in the short term than in the long term, and long-term debt carries greater interest-rate risk. ${ }^{27}$ As Monroe County learned, however, this cost-saving does not come free of charge: it also introduces the threat of rollover risk. ${ }^{28}$

Rollover risk effectively arises any time short-term debt is used to fund long-term projects. ${ }^{29}$ Until the project is completed, its revenues may be unavailable to repay the short-term debt; thus, the main source of repayment of the short-term debt during the project term is the proceeds of newly issued short-term debt. ${ }^{30}$ The shorter the term of the debt, the more often it will mature and be repayable during the project term, with each maturity presenting a separate rollover risk. ${ }^{31}$ With the rise of the so-called "shadow banking” sys-

${ }^{24}$ Enrica Detragiache, Rational Liquidity Crises in the Sovereign Debt Market: In Search of a Theory, 43 IMF STAFF PAPERS 545, 546 (1996).

${ }^{25}$ Id.; see infra notes 186-189 and accompanying text (explaining why even a mere "technical" debt default could harm the real economy).

${ }^{26}$ Roubini, supra note 20 (explaining that the maturity length of treasury debt has decreased significantly since the 1990 s because it is much less expensive to finance short-term debt than longer-term debt).

${ }^{27} \mathrm{Id}$.

${ }^{28}$ See id. (explaining that the average rate of maturity for U.S. government bonds has fallen sharply since the 1990s and explaining how this contributes to increasing rollover risk).

${ }^{29}$ See Viral Acharya et al., Rollover Risk and Market Freezes, 66 J. FIN. 1177, 1179 (2011) (providing examples of short-term projects that were financed with short-term debt during the 2007-2008 financial crisis). Economists sometimes refer to the use of short-term debt to fund long-term projects as a form of maturity transformation or as an asset-liability mismatch. See id. at 1177.

${ }^{30}$ See Brunnermeier, supra note 21, at 91-92 (explaining rollover risk). A similar risk occurs in a financial market where there is a growing reliance on short-term repo contracts, in which a firm raises capital by selling an asset one day with the promise to repurchase it on a future date at a higher price. $I d$. at 80 (explaining that there is an increasing reliance by investment banks on such "overnight financing”).

${ }^{31}$ See Roubini, supra note 20 (explaining rollover risk and how the average length of U.S. debt has decreased rapidly in the last decade). 
tem-a system of financing outside of traditional banking channels-rollover risk is becoming increasingly common, even outside of government finance. ${ }^{32}$

\section{B. Rollover Risk's Application to U.S. Debt}

The U.S. government relies heavily on short-term debt funding. ${ }^{33}$ As a result, some estimates suggest that the U.S. government has to roll over half of its debt every two years. ${ }^{34}$ A recent article estimates that the U.S. government will have to roll over seventy-one percent of its privately held debt over the next five years. ${ }^{35}$ Additionally, the government depends on short-term debt to finance the federal budget deficit—which was \$1.1 trillion in 2012. ${ }^{36}$ So long as the United States maintains a large deficit funded by the issuance of short-term debt, it creates a risk of being unable to raise the funding necessary to avoid default. ${ }^{37}$

${ }^{32}$ See Acharya et al., supra note 29, at 1179 (explaining how rollover risk contributed to the failure of Bear-Stearns, a global investment bank, in March 2008). Because shadow banking allows for financing outside of traditional banking channels, it also avoids the need for traditional modes of bank intermediation between capital markets and the users of funds. Brunnermeier, supra note 21, at 79; see Gary Gorton \& Andrew Metrick, Securitized Banking and the Run on Repo, 104 J. Fin. ECON. 425, 425 (2012) (using the term "securitized banking system" rather than "shadow banking system”). It includes, for example, asset-backed commercial paper (“ABCP”) conduits and structured investment vehicles ("SIVs"), which routinely issue short-term commercial paper to invest in financial assets having long-term maturities. Brunnermeier, supra note 21, at 79. Rollover risk is also present in the practice of repo lending, whereby one party purports to sell a financial asset (typically a security) to another party and promises to "repurchase" the asset at a later time. See SCotT Besley \& Eugene F. BRigham, PRinciples of FinANCE 29 (4th ed., 2008) (defining “repo lending”). See generally Gorton \& Metrick, supra (explaining that repo agreements contributed to creating the shadow banking equivalent of a bank run during the 2008 financial crisis).

${ }^{33}$ John H. Cochrane, Professor of Fin., Univ. of Chi., Address at Second Annual Roundtable on Treasury Markets and Debt Management, Department of the Treasury: Having Your Cake and Eating it Too: The Maturity Structure of US Debt 2 (Nov. 15, 2012), available at http://faculty. chicagobooth.edu/john.cochrane/research/papers/Maturity_of_debt.pdf, archived at http://perma.cc/ 0EAtnFaKxe3.

${ }^{34} \mathrm{Id}$.

${ }^{35}$ Caroline Baum, Four Numbers Add Up to an American Debt Disaster, BLOOMBERG (Mar. 28, 2012, 7:00 PM), http://www.bloomberg.com/news/2012-03-28/four-numbers-add-up-to-anamerican-debt-disaster.html, archived at http://perma.cc/04XDX1HGcWQ.

${ }^{36}$ Rollover Roulette, ECONOMIST, Oct. 14, 2010, at 88, 90-91 (explaining the risks associated with short-term financing of debt and how countries such as the United States are attempting to mitigate those risks); Annie Lowrey, U.S. Reports \$1.1 Trillion Deficit in '12, a Reduction, N.Y. TIMES, Oct. 13, 2012, at A16; Roubini, supra note 20.

${ }^{37}$ Roubini, supra note 20. In other words, deficit spending is putting the U.S. government at the mercy of its creditors. Id.; cf. Paolo Manasse et al., Predicting Sovereign Debt Crises 4, 26 (Int'l Monetary Fund, Working Paper No. 03/221, 2003) (finding that historically high illiquidity, especially as measured by the use of short-term debt, is associated with a high probability of entering a debt crisis). 
Policy responses to the expanding shadow-banking system might also increase government rollover risk. A senior advisor to the U.S. Treasury recently argued, for example, that the financial crisis revealed a problem of "excessive private money-creation in response to an insufficient supply of [U.S.] Treasury bills." ${ }^{38}$ In other words, investors demanded shadow-banking investments as a comparable short-term financing option because of a shortage of Treasury bills. A "simple solution to this problem," this senior advisor contended, would be to "increase the supply of Treasury bills." ${ }^{39}$ Such a solution would attract funding away from risky investments and into U.S. debt securities. ${ }^{40}$ The downside, however, is that issuing more Treasury bills would create more "rollover risk[] from the system migrating from the (shadow) banking system to the balance sheet of the [United States]." 41

Ongoing political disputes over the federal debt ceiling further exacerbate rollover risk by limiting the amount of new debt that can be issued to repay maturing debt. ${ }^{42}$ Prior to 1939 , Congress-which under the Constitution has the authority "to borrow money on the credit of the United States" 43 - micromanaged the types and amounts of debt securities that the Treasury could issue. The debt ceiling was introduced in 1939 as a constraint on the

${ }^{38}$ Zoltan Pozsar, A Macro View of Shadow Banking: Do T-Bill Shortages Pose a New Triffin Dilemma?, in Is U.S. GOVERnMENT DeBT DifFERENT?, supra note 1, at 35, 41. The term "U.S. Treasury securities," sometimes abbreviated as "U.S. Treasuries," refers to debt securities of the U.S. government. See Treasury Securities \& Programs, TREASURYDIRECT, http://www.treasury direct.gov/indiv/products/products.htm, archived at http://perma.cc/0kLcyu99Hua (last visited Jan. 14, 2014) (providing a summary of the different types of U.S. Treasury securities). Treasury bills are short-term U.S. Treasury securities. Neil Irwin, What's Happening in the Treasury Bill Market Today Should Terrify You, WASH. POST WONKBLOG (Oct. 8, 2013, 2:10 PM), http://www.washington post.com/blogs/wonkblog/wp/2013/10/08/whats-happening-in-the-treasury-bill-market-today-shouldterrify-you/, archived at http://perma.cc/0SQwhr7TzFo (explaining that Treasury bills are "issued for 30, 60, or 90 days").

${ }^{39}$ Pozsar, supra note 38, at 42.

${ }^{40} \mathrm{Id}$.

${ }^{41}$ Id. The senior advisor nonetheless believes that, notwithstanding such "increased [government] rollover risk[]," the externalities would be "less costly and disruptive" than the systemic danger to the economy that would result by allowing the increase of risky private investments. Id. at 43 .

${ }^{42}$ See Jonathan Weisman \& Ashley Parker, Boehner Urges G.O.P. Solidarity in 'Epic Battle,' N.Y. TIMES, Oct. 5, 2013, at A1 (demonstrating that political disputes might lead to questions as to whether Congress will cooperate to raise the debt ceiling in time to avoid a default). This assumes, of course, that enough other debt was issued since the maturing debt was issued so that the federal debt limit would be faced. Even given that assumption, however, I would argue that additional new debt should be issued if its proceeds to "simultaneously" repay the maturing debt, because-repayment and interest cost aside - that issuance would not create a net increase in outstanding debt.

${ }^{43}$ U.S. ConST. art. I, § 8, cl. 2. 
U.S. Treasury, which was then delegated limited congressional authority to manage the issuance of national debt. ${ }^{44}$

At first blush, the federal debt ceiling does not seem especially problematic because it is artificial and can be raised by Congress to avoid default. ${ }^{45}$ In fact, Congress has modified the debt ceiling over ninety times since 1940, ${ }^{46}$ and at least ten times since $2001 .^{47}$ History reveals, however, that not all of these modifications are passed in a timely manner. Most notably, on April 26, 1979 the federal debt ceiling prevented the U.S. government from borrowing sufficient funds to repay its maturing debt, thereby triggering a default. ${ }^{48}$ The government also defaulted on its debt coming due on May 3rd and 10th of that year, in part due to the debt ceiling. ${ }^{49}$

On several other occasions, the failure to timely modify the federal debt ceiling pushed the government close to default, adding to the uncertainty that the government will in fact repay its short-term commitments. Congress and the executive branch of the government failed to reach a timely agreement regarding the federal debt ceiling in 1985 and again between October 1995 and March 1996. ${ }^{50}$ One of these failures prompted the rating agency Standard \& Poor's to issue a warning that "the standoff was adversely affecting the credibility of the U.S. Treasury in the world market." ${ }^{51}$ Moody's Investors Service (Moody's) also announced that it was considering downgrading the credit rating of $\$ 387$ billion of U.S. Treasury debt. ${ }^{52}$ An examination of the yield spreads between corporate commercial paper and Treasury bills of the

${ }^{44}$ Richard Sylla, U.S. Government Debt Has Always Been Different!, in Is U.S. GoverNMENT DEBT DIFFERENT?, supra note 1, at 1, 11.

${ }^{45}$ Michael W. McConnell, Origins of the Fiscal Constitution, in Is U.S. GovERnMENT DEBT DIFFERENT?, supra note 1 , at 45 , 48. Because the debt ceiling is denominated in dollars, not percentage of national income, it is effectively lowered by inflation over time unless Congress increases it. Neil H. Buchanan \& Michael C. Dorf, How to Choose the Least Unconstitutional Option: Lessons for the President (and Others) from the Debt Ceiling Standoff, 112 COLUM. L. REV. 1175, 1187 (2012).

${ }^{46}$ McConnell, supra note 45, at 48.

${ }^{47}$ D. Andrew Austin \& Mindy R. Levit, Cong. Research Serv., RL31967, The DebT LIMIT: HISTORY AND RECENT INCREASES 1 (2013).

${ }^{48}$ Terry L. Zivney \& Richard D. Marcus, The Day the United States Defaulted on Treasury Bills, 24 FIN. REV. 475, 475 (1989).

${ }^{49} I d$. The government's delay in paying that debt was due to the large number of small investors holding the debt and the failure of word-processing equipment used to prepare check schedules. Id.; see infra notes 180-184 and accompanying text (discussing the economic harm caused by these defaults).

${ }^{50}$ McConnell, supra note 45, at 48.

${ }^{51}$ Srinivas Nippani et al., Are Treasury Securities Free of Default?, 36 J. Fin. \& QuANT. ANAlysis 251, 252 (2001); cf. Robert Hurtado, Debt Ceiling Impasse Dampens Bond Prices, N.Y. TimES, Nov. 11, 1995, at A40 (explaining how the political uncertainty affected bond prices).

${ }^{52}$ Nippani et al., supra note 51, at 252. 
same maturities found that spreads narrowed during this crisis, indicating that the market charged a default-risk premium on the Treasury bills. ${ }^{53}$

Debt-ceiling standoffs typically arise when different parties control the Presidency and at least one house of Congress, ${ }^{54}$ and appear to be the result of fundamental disagreements over the federal government's size and role. ${ }^{55} \mathrm{~A}$ debt ceiling “crisis" occurred in 2011, for example, when certain members of Congress attempted to use the debt ceiling to force the Obama administration to accept spending cuts. ${ }^{56}$ Even more recently, in 2013, the Republican majority in Congress conditioned any raise in the debt ceiling on spending "cuts and reforms." ${ }^{57}$ As a result, Congress was able to reach a debt ceiling agreement only on the eve of a default, creating speculation that the United States might actually default on some of its debt. ${ }^{58}$ As long as these types of fundamental disagreements exist, members of Congress may well continue to "play[] politics" with the debt ceiling and push the nation, at times, uncomfortably close to default. ${ }^{59}$

\section{How Could A U.S. Debt Default Be Avoided?}

Because rollover risk makes a U.S. debt default more likely, the government should pay greater attention to managing that risk. As a senior advisor to the U.S. Treasury observed, "[p]roposing that public debt management should incorporate considerations other than minimizing the cost of debt issuance may sound radical ...., ${ }^{60}$ Nonetheless, in light of the increasing rollover risk, "central banks today [including the U.S. Federal Reserve] [should] have an equally

${ }^{53}$ Id. Yield spreads measure the relative investment risk between two (or more) debt securities. See id. at 254.

${ }^{54}$ McConnell, supra note 45, at 48.

${ }^{55}$ See Nippani et al., supra note 51, at 252.

${ }^{56}$ McConnell, supra note 45, at 48 (using the term “crisis”); Glenn Kessler, Explaining the Debt Ceiling Debate, WASH. POST BlOG (June 29, 2011, 6:00 AM), http://www.washingtonpost.com/ blogs/fact-checker/post/explaining-the-debt-ceiling-debate/2011/06/28/AGVM80pH_blog.html, archived at http://perma.cc/0QDcXTeynYL.

${ }^{57}$ Ashley Parker, Boehner Sees Showdown Over Raising Debt Limit, N.Y. TIMES, Aug. 28, 2013, at A17 (reporting that the Secretary of the Treasury warned Congress that the United States would reach its borrowing limit in mid-October 2013 and would likely be unable to pay all of its bills without raising the debt ceiling).

${ }^{58}$ Jonathan Weisman \& Ashley Parker, Shutdown Is Over, N.Y. TimES, Oct. 17, 2013, at A1 (explaining that Congress approved an increase in the debt ceiling within a day of the Treasury running out of money to pay its obligations and that the agreement also ended a sixteen-day government shutdown caused by Congress's inability to reach an agreement over a spending bill).

${ }^{59}$ Kessler, supra note 56. But see Annie Lowrey, Lingering Confusion in Debt Ceiling's Temporary Fix, N.Y. TIMES, Oct. 18, 2013, at B3 (explaining that the debt ceiling bill passed in October 2013 included a "default prevention" section, which allows President Obama to unilaterally increase the debt ceiling until February 7, 2014).

${ }^{60}$ Pozsar, supra note 38 , at 43. 
important mandate of focusing on financial stability ...."61 The discussion below illustrates the U.S. government's considerable, though not unlimited, flexibility to exercise that mandate.

\section{A. Monetizing the Debt}

One route to minimizing rollover risk would be through monetizing the country's debt. "Monetizing" the debt is a somewhat vague term, referring to monetary steps - including quantitative easing and printing money-that the government can take for the sole purpose of facilitating its debt payment. ${ }^{62}$ This is in contrast to monetary steps taken for other purposes, such as achieving price stability or maximizing economic growth. ${ }^{63}$

\section{Quantitative Easing}

Quantitative easing ("QE") is the most popular way to monetize government debt, and indeed the terms "monetizing the debt" and "QE" are often used interchangeably. ${ }^{64} \mathrm{QE}$ is generally defined as a policy that, unconventionally, increases the monetary base with the goals of reducing the cost of government debt and increasing liquidity. ${ }^{65}$

Typically, a central bank engages in QE by instituting a lending program or purchasing financial assets, including government securities. ${ }^{66}$ In the Unit-

${ }^{61}$ Id. One may query how that mandate would parse with the Federal Reserve's "dual mandate" to "promote effectively the goals of maximum employment, stable prices and moderate long-term interest rates.” Federal Reserve Act, 12 U.S.C. § 225a (2012). Furthermore, it may be difficult to reach an optimal tradeoff between rollover risk and interest-rate cost on government debt. Cf. E-mail from Deborah J. Lucas, Sloan Distinguished Professor of Fin., Mass. Inst. of Tech., to author (Aug. 28, 2013) (on file with author) (observing that "it is difficult to specify what the tradeoff function between higher rates and liquidity benefits should be").

${ }^{62}$ Mike Shortridge, QE4: Monetizing the Debt with No Possible Exit, WASH. TIMES (Dec. 24, 2012), http://communities.washingtontimes.com/neighborhood/politics-blue-collar/2012/dec/24/qe 4-monetizing-debt-no-possible-exit/, archived at http://perma.cc/0tE5pDKjMYa.

${ }^{63}$ Daniel L. Thornton, Monetizing the Debt, ECON. SynOpSES, May 19, 2010, at 1, 1 (explaining that in a growing economy, the money supply must expand over time in order to promote stability and maximum economic growth). A possible-albeit overly broad-definition of monetizing debt is the use of "money creation" to permanently finance deficit spending. See David Andolfatto \& $\mathrm{Li} \mathrm{Li}$, Is the Fed Monetizing Government Debt?, ECON. SYNOPSES, Feb. 1, 2013, at 1,1 (using this definition).

${ }^{64}$ See Andolfatto \& Li, supra note 63, at 1 (using the term "monetizing the debt" to describe quantitative easing).

${ }^{65}$ Brett W. Fawley \& Christopher J. Neely, Four Stories of Quantitative Easing, 95 FED. RES. BANK OF ST. LOUIS REV. 51, 52-53 (2013). The monetary base consists of both currency and reserves in the economy. Id. at 53.

${ }^{66}$ Id. at 52; Stephanie Flanders, Is Quantitative Easing Really Just Printing Money?, BBC NEWS BLOG (Feb. 18, 2009, 12:59 PM), http://www.bbc.co.uk/blogs/thereporters/stephanie 
ed States, the Federal Reserve System (the "Fed") engages in QE by buying U.S. Treasury securities indirectly. ${ }^{67}$ The Fed pays for these securities with reserves it creates "by a stroke of the pen," 68 which some consider the "effective equivalent of money printing." 69

This process reduces the government's cost of borrowing: although the Treasury continues to pay interest to the Fed on its debt, the Treasury will not have to repay the principal as it would to an outside investor. ${ }^{70} \mathrm{QE}$ also increases U.S. government liquidity. ${ }^{71}$ That reduction in cost and increased li-

flanders/2009/02/obtaining-the-right-to-print-m.html, archived at http://perma.cc/0ci4t9mDkC8 (discussing government securities).

${ }^{67}$ See Marshall Gittler, Why Quantitative Easing Isn't Printing Money, CNBC (May 23, 2013, 3:31 AM), http://www.cnbc.com/id/100760150, archived at http://perma.cc/J9DE-SWNH (explaining how the Fed uses QE in the United States); Quantitative Easing Explained, BANK OF ENG., http://www.bankofengland.co.uk/monetarypolicy/pages/qe/default.aspx, archived at http://perma.cc/8QYX-UVK2 (last visited Jan. 14, 2014) (explaining QE in the United Kingdom). The Fed typically buys securities from commercial banks and other private institutions because it may not legally purchase securities from the Treasury directly. See Thornton, supra note 63, at 2; see also 12 U.S.C. $\S 355$ (2012). It appears that central banks are often prohibited, under national law, from purchasing debt directly from the government. Flanders, supra note 66 (noting that the Bank of Japan and Bank of England are both legally forbidden to buy debt directly from their own governments).

68 Bob Eisenbeis, Three Myths and Misunderstandings, Fin. SENSE (Jan. 14, 2013), http://www.financialsense.com/contributors/bob-eisenbeis/three-myths-misunderstandings, archived at http://perma.cc/H3C-E66J; see Pedro da Costa, The Fallacy of Fed 'Profits' (and 'Losses'), REUTERS BLOG (Feb. 20, 2013), http://blogs.reuters.com/macroscope/2013/02/20/the-fallacyof-fed-profits-and-losses/, archived at http://perma.cc/03br5tC49Yo.

${ }^{69}$ Agustino Fontevecchia, Billionaire Paul Singer: The U.S. Has a Big Debt Problem and the Fed Is Making It Worse, ForBES (May 8, 2013, 1:11 PM), http://www.forbes.com/sites/afont evecchia/2013/05/08/u-s-is-insolvent-banks-sitting-on-trillions-in-derivatives-we-cant-see-and-qemoney-printing-is-making-it-worse-singer-at-ira-sohn/, archived at http://perma.cc/0QEfh8zyzZQ; see Eisenbeis, supra note 68. Simplistically, QE can be viewed as the Fed issuing Federal Reserve liabilities in exchange for Treasury debt, thereby effectively moving sovereign debt from the Treasury's balance sheet to that of the Fed. Eisenbeis, supra note 68 ("Looking at the Fed's portfolio of securities from the perspective of the nation's consolidated balance sheet, we see that one form of government debt (Treasury debt) is taken out of circulation and replaced with another form of government debt (Federal Reserve liabilities).").

${ }^{70}$ See QE, or Not QE?, ECONOMIST, July 14, 2012, at 66, 66 (explaining QE). By purchasing Treasury securities, some argue that the Fed also gives the appearance of increasing investor demand for those securities without real money being paid, which in turn drives down the government's cost of borrowing by lowering the interest rate payable on Treasury securities. See id.

${ }^{71}$ See da Costa, supra note 68. QE increases government liquidity by taking U.S. government debt out of circulation and replacing it with Federal Reserve liabilities that do not necessarily have to be paid. See id. When the Fed purchases U.S. Treasury securities, the debt evidenced by those securities is taken out of circulation and "effectively retired." Id. The Treasury continues, however, to pay the Fed interest, from which the Fed extracts its expenses and dividend payments and returns the remainder to the Treasury. Id. But cf. Gavyn Davies, Will Central Banks Cancel Government Debt?, FIN. TIMES BLOG (Oct. 14, 2012, 3:27 PM), http://blogs.ft.com/gavyndavies/ 2012/10/14/will-central-banks-cancel-government-debt/?, archived at http://perma.cc/WE2K-UX3T (arguing that the purchased Treasury securities are "parked ... temporarily" at the Fed, only to be 
quidity can at least marginally help to avoid a U.S. debt default. But QE is not a real-time remedy that can instantly generate funds to refinance maturing debt. Moreover, QE can be costly, sparking inflation if banks use their newfound reserves to increase lending. ${ }^{72}$

\section{Printing Money}

Although QE can be considered the effective equivalent of printing money, ${ }^{73}$ the U.S. government can also literally print money to pay its debt, thereby avoiding default. ${ }^{74}$ The government has this flexibility-indeed, it

sold back to the private sector in the future). Another argument as to why QE increases government liquidity is that by lowering the government's cost of borrowing, QE can encourage banks to lend, firms to invest, and individuals to consume. See Fawley \& Neely, supra note 65, at 51; da Costa, supra note 68. In this way, QE can influence the economy's level of output and employment. See Fawley \& Neely, supra note 65, at 51. An increase in output and employment can then raise tax revenues and provide the government with more money to pay its debts. See id. at 72 (explaining how a financial crisis negatively affects a government's ability to raise taxes and pay its national debt). The connection between interest rates and government liquidity, however, is not without risk. Chris Isidore, Is the Fed Playing with Fire?, CNNMONEY (Oct. 5, 2010, 4:05 PM), http://money.cnn.com/2010/10/05/news/economy/Fed_quantitative_easing/index.htm, archived at http://perma.cc/04p5BxrdVw1 (highlighting some negative side effects of QE, including a decline in the value of the dollar, which in turn could cause interest rates to rise).

${ }^{72}$ Gittler, supra note 67 (arguing that QE is not necessarily inflationary because the amount of reserves a bank has is only one factor in determining whether or not to increase lending). QE might also raise questions of securities fraud. See Securities Exchange Act of 1934, 15 U.S.C. $\S \S 78 a-78 p p$ (2006). Rule 10b-5 of the Securities Exchange Act of 1934, for example, criminalizes employing "any device, scheme, or artifice to defraud ... in connection with the purchase or sale of any security.” 17 C.F.R. § 240.10b-5 (2013) (authorized by 15 U.S.C. § 78j). This provision has been used to punish market manipulation in which companies buy and sell their own securities in order to affect the market price. Manuel A. Utset, Fraudulent Corporate Signals: Conduct as Securities Fraud, 54 B.C. L. REV. 645, 698-99 (2013) (explaining that “Section 10(b) prohibits manipulative and deceptive behavior in connection with the purchase of a sale or security"). Arguably, that is partly what the government itself does if QE has the effect of increasing the appearance of investor demand for Treasury securities. See supra note 70 and accompanying text (explaining that QE potentially has the effect of driving up demand for government securities). The counterargument, however, is that because the Fed's QE operations are disclosed, the market should not falsely perceive investor demand.

${ }^{73}$ See supra note 69 and accompanying text (explaining that like printing money, QE increases the amount of currency in circulation).

${ }^{74}$ Herring, supra note 16, at 22 (explaining that "[governments] can almost always print enough domestic currency to service their debts in a timely manner"); see also Catherine New, Could the U.S. Print Its Way Out of the Debt Crisis?, DAILYFInANCE (July 28, 2011, 5:00 PM), http://www.dailyfinance.com/2011/07/28/could-the-u-s-print-its-way-out-of-the-debt-crisis/, archived at http://perma.cc/0msBSkYVpgX (explaining how printing money could enable the United States to repay its debt but also highlighting the risk of inflation that could accompany this solution). 
has the flexibility generally to monetize its debt—because the U.S. dollar is a major reserve currency, and is therefore in high demand. ${ }^{75}$

Just as with QE and other forms of monetizing its debt, the U.S. government would face negative consequences, such as inflation, that would result from printing money to pay its debt. Inflation can also motivate investors to demand higher interest rates, which would "balloon the cost of servicing the federal debt." 76 The former president of the Kansas City Federal Reserve has even argued that the inflation resulting from printing money to pay U.S. debt could threaten American living standards as well as destroy the Fed's independence and credibility. ${ }^{77}$

Moreover, the government's flexibility to print money or otherwise monetize its debt to avoid default could change. ${ }^{78}$ The U.S. dollar could, for example, lose its role as the international reserve currency, thereby making it harder, or at least more inflationary, to sell dollars. ${ }^{79}$ Reserve currencies have been displaced before. The pound sterling was the world's first major reserve currency, but the U.S. dollar began to dominate after World War I. ${ }^{80}$ Since the U.S. dollar's rise, several countries have attempted to replace it with their

${ }^{75}$ Herring, supra note 16, at 25-28 (discussing the role of the dollar in the international economy). Because the U.S. dollar is the benchmark for world prices and is used to settle cross-border trades, there is a unique demand for dollars: countries need to keep stores of dollar reserves, both as a float and to bolster confidence in their own currencies. Climbing Greenback Mountain, ECONOMIST, Sept. 24, 2011, at 12, 13.

${ }^{76}$ Patrice Hill, Induced Inflation Feared as a Way to Cut Debt, WASH. TIMES (Feb. 19, 2010), http://www.washingtontimes.com/news/2010/feb/19/induced-inflation-feared-as-way-to-cutdebt/?page=all, archived at http://perma.cc/X2UK-8XWU (quoting Alice Rivlin, the former director of the Congressional Budget Office); see also Peter S. Goodman, Printing Money-and Its Price, N.Y. TIMES, Dec. 28, 2008, at WK1 (discussing other negative consequences of inflation, including a declining dollar resulting in more expensive imported goods and demand for increased interest rates among foreign borrowers, which will prompt increased interest rates for home and automobile buyers, and business and credit card holders). But cf. Herring, supra note 16, at 22 (explaining that increasing inflation can make it easier for the government, as debtor, to repay debt that has fixed principal and interest).

${ }^{77}$ Hill, supra note 76 (quoting Thomas Hoenig).

${ }^{78}$ See Herring, supra note 16, at 25-28 (explaining that the dollar is currently used as reserve currency but that this could change).

${ }^{79}$ See id. at 28-29 (describing the threats to the dollar's status as the leading reserve currency). In theory, any nation can monetize its debt-or at least debt payable in the nation's currency-by printing money, but doing so necessarily increases the money supply and so causes inflation. Id. at 22-23 (explaining that countries that are especially adverse to inflation might prefer a default rather than the inflation that would be triggered by printing money). If the currency is a major reserve currency - as the U.S. dollar currently is - the natural supply of that currency would be larger than the supply of a non-major reserve currency. See id. at 25 (explaining that the United States enjoys an "extra degree of freedom" in its ability to print money "because of the international role of the dollar"). Therefore, the inflationary effect caused by printing the money needed to pay the nation's debt would be smaller than if the nation did not have a major reserve currency. See id.

${ }^{80}$ Id. at 26. 
currency: Japan and the euro zone of the European Union both have hoped their respective currencies might serve as the principal reserve currency. ${ }^{81}$

In the future, the Chinese renminbi (also called yuan) may pose a real threat to the U.S. dollar's status. The Chinese government has already taken steps towards enhancing the renminbi's international role, giving most companies the right to pay for imports in renminbi and allowing many companies to sell exports for renminbi. ${ }^{82}$ To replace the U.S. dollar, however, China would have to abandon many of its current policies, like artificially setting the renminbi exchange rate. ${ }^{83}$

\section{B. Asset Sales}

The U.S. government could also consider selling assets as part of its debt-reduction measures. This could even include the "monetization" of future tax revenues or quasi-production payments of mineral rights. ${ }^{84}$ Some experts argue, for example, that "[s]overeigns can almost always sell sufficient assets to service their debts." 85

That assumes, of course, that those sales could be made on a timely enough basis to pay maturing debt, which may not always be possible. As part of its proposed bailout, for example, Greece was required to sell assets to raise funds in accordance with specified deadlines. ${ }^{86}$ But as of June 2013, Greece was still struggling to attract buyers for assets like its natural gas company and its grid-operating subsidiary. ${ }^{87}$ The IMF has called Greece's

${ }^{81} I d$. at 29.

${ }^{82} I d$. at $32-33$.

${ }^{83} \mathrm{Id}$. at 33.

${ }^{84}$ See Jim Millstein, Burning the Furniture to Heat the Home-The Potential Role of Asset Sales in Funding the Federal Government's Deficits, in Is U.S. GOVERNMENT DEBT DiFFERENT?, supra note 1 , at $151,163,167$ (explaining that the U.S. government's assets likely amounted to $\$ 4$ trillion in 2011 and concluding that the United States should consider using the sale of its assets as a debt solution).

${ }^{85}$ Herring, supra note 16, at 23.

${ }^{86}$ Millstein, supra note 84, at 162 (explaining that Portugal and Ireland were also required to sell assets).

${ }^{87}$ Greece Dismisses Fears of Funding Gap from Asset Sale Delays, ReUTERS (June 25, 2013, 1:09 PM), http://www.reuters.com/article/2013/06/25/greece-funding-idUSL5N0F13HX20130625, archived at http://perma.cc/7DNB-23JT (discussing Greece's difficultly in securing buyers for national assets, such as its national gas company); Christos Ziotis, Greek Asset-Sales Plan Dealt Blow as Gazprom Declines Depa Bid, BloOMBERg (June 10, 2013, 12:29 PM), http://www.bloom berg.com/news/2013-06-10/greek-asset-sales-plan-dealt-blow-as-gazprom-declines-depa-bid.html, archived at http://perma.cc/0XPfL7vmeUY (discussing Greece's difficulty in securing buyers for its grid operating company, Desfa SA and its gas monopoly, Depa SA). 
progress "extremely disappointing," 88 as Greece has been able to raise only a fraction of its target from the sale of government assets since $2010 .{ }^{89}$

The United States may face similar problems if it attempts to raise funds quickly through asset sales; it may be difficult to attract sufficient investors, and increasing the supply of (non-unique) assets relative to a fixed demand will likely decrease the return on assets sold. ${ }^{90}$ In addition to these difficulties, asset sales may well be politically unpopular, like "mortgaging the future.”

\section{Limits on Avoiding Default}

Notwithstanding all this flexibility, there are additional limits on the ability to avoid a U.S. national debt default. These limits include the possibility that the magnitude of the problem could be too large for the United States to fix on its own. ${ }^{91}$ A related possibility is that estimates about the size of the U.S. debt might understate the magnitude of the problem because those estimates fail to consider hidden liabilities. ${ }^{92}$

\section{The Problem Could Be Too Large}

An obvious limit is that the problem could simply be too large. A large increase in the size of government debt and the resulting magnitude of the problems posed by it could be triggered, for example, by a problem in the private sector that would require a massive U.S. government intervention to prevent a systemic collapse. ${ }^{93}$ The Dodd-Frank Act, passed in 2010, attempts

${ }^{88}$ Ziotis, supra note 87.

${ }^{89}$ Harry Papachristou, Update 1-Greece PM Pleads for Some Slack in Latest EU/IMF Inspection, REUTERS (Sept. 18, 2013, 11:03 AM), http://www.reuters.com/article/2013/09/18/ greece-bailout-idUSL5N0HE2CT20130918, archived at http://perma.cc/Z53L-K2ZE (explaining that "Greece has clinched privatization deals worth 3.6 billion euros since its bailout started in 2010, compared with an initial target to raise 22 billion euros over that period”); Robin Wigglesworth \& Kerin Hope, Greek Asset Sales Behind Target, Fin. TiMES (Jan. 30, 2012, 7:43 PM), http://www.ft.com/intl/cms/s/0/e91b970e-4b63-11e1-b980-00144feabdc0.html\#axzz2YSsQUCgf, archived at http://perma.cc/PPS3-E7FZ (explaining that it has been difficult to attract investors to buy Greece's assets).

${ }^{90}$ Millstein, supra note 84, at 162 ("However, states do not part with assets lightly, in particular with land and mineral rights. National pride in ownership can be a large obstacle, as can security and environmental concerns.”).

${ }^{91}$ See infra notes 93-101 and accompanying text (explaining that the size of the U.S. debt could rapidly increase).

${ }^{92}$ See infra notes 102-110 and accompanying text (explaining the use of special purpose entities).

${ }^{93}$ See Comment to Shortridge, supra note 62 ("[W] cliff is the bond bubble bursting, spiking interest rates, and causing a massive crash in the deriva- 
to mitigate this risk. ${ }^{94}$ It limits the Fed's ability to act as a lender of last resort, and it requires systemically important financial institutions to draw up "living wills" that specify how they could liquidate, if needed, with minimal systemic impact. ${ }^{95}$ But in the author's experience as a bankruptcy lawyer, it is rare that a firm is able to accurately predict during good times what might happen during bad times. It therefore appears that the Fed will ultimately face the need to act as a lender of last resort at least in some cases. ${ }^{96}$

Moreover, because it is possible that the Fed will eventually need to act as a lender of last resort, the Dodd-Frank Act's limitations on the Fed's ability to act in that capacity may well be "penny-wise but pound-foolish." A systemically important financial institution could end up defaulting, with systemic consequences, precisely because the Fed is unable to act as a lender of last resort. ${ }^{97}$ The cost of trying to address those systemic consequences could itself "bankrupt" the country.

The Dodd-Frank Act also ignores the systemic implications of financial markets themselves. ${ }^{98}$ In today's era of increasing disintermediation, financial markets can be triggers and transmitters of systemic risk. For example, the recent financial crisis was at least partly market driven. ${ }^{99}$ Subprime mortgage loans had been bundled together as collateral to partially support the payment of mortgage-backed securities. ${ }^{100}$ When home prices began falling, some of the mortgage-backed securities began defaulting or were downgraded, thereby destroying investor confidence in debt ratings and causing debt markets more broadly to collapse. ${ }^{101}$ If financial markets collapse with systemic consequences, the cost of trying to address those consequences could, again, "bankrupt" the country.

tives market. i [sic] don't see uncle sam [sic] printing up \$70 trillion to cover the [derivatives] exposure of just JP Morgan ....”).

${ }^{94}$ See Dodd-Frank Wall Street Reform and Consumer Protection Act § 1101, 13 U.S.C. § 343

(2012) (limiting the Fed's ability to act as a lender of last resort); see Dodd-Frank Act $\S 165,12$ U.S.C. § 5365 (2012) (requiring living wills).

${ }_{95}$ Iman Anabtawi \& Steven L. Schwarcz, Regulating Ex Post: How Law Can Address the Inevitability of Financial Failure, 92 TEX. L. REV. 75, 106, 113 (2013).

${ }^{96}$ See id. at $105-06$.

${ }^{97}$ Id. at 106 ("Perversely, Dodd-Frank's limitation has actually increased the risk that an important financial firm will collapse, with systemic consequences.”).

${ }^{98}$ See id. at 130-31 (explaining how the Dodd-Frank Act limits the ability of the Treasury Department and the Fed to rescue failing firms, even where their failure may have system-wide consequences for the nation's economy).

${ }^{99}$ See Steven L. Schwarcz, Controlling Financial Chaos: The Power and Limits of Law, 2012 WIS. L. REV. 815, 817 (explaining how the collapse of Lehman Brothers in 2008 was triggered by "the collapse of the market for mortgage-backed securities").

\footnotetext{
${ }^{100} I d$.

${ }^{101} I d$.
} 


\section{Special-Purpose Entities and Hidden Debt}

There is also an insidious problem of hidden debt. In the United States, both federal and state government is increasingly operated and financed through government-sponsored special-purpose entities ("SPEs"). ${ }^{102}$ Originally, SPEs were used to bypass restrictions on government borrowing, such as debt limits and jurisdiction limitation; however, SPEs increasingly resemble those used by corporations as a tool to raise off-balance-sheet financing. ${ }^{103}$ For example, some states establish "enterprises," which are funded by revenue bonds, "repayable solely from the profits of the enterprise."104 Theoretically, the state allocates the risk of these enterprises failing to be profitable to investors without allowing "legal recourse to the state's general funds or tax revenues." 105

In the United States, the debt of government-sponsored SPEs is rarely disclosed as debt of the government because the government is not legally liable on that debt, either directly or as a guarantor. ${ }^{106}$ Nonetheless, because a default by one of these entities could destroy the reputation and debt rating of its government sponsor, there are numerous precedents indicating that the government will routinely support its sponsored SPEs - even though it is not legally obligated to do so. ${ }^{107}$ Indeed, the U.S. government stepped in to support the debt of its government-sponsored SPEs Fannie Mae and Freddie Mac in the recent financial crisis, notwithstanding that such debt was not legally the government's obligation. ${ }^{108}$

${ }^{102}$ Steven L. Schwarcz, The Use and Abuse of Special-Purpose Entities in Public Finance, 97 MinN. L. REV. 369, 370-72 (2012) (explaining that some states, including New York and Virginia, issue almost all of their debt through SPEs).

${ }^{103} I d$.

${ }^{104} I d$. at 375 .

${ }^{105} \mathrm{Id}$. (explaining that investors are presumably rewarded for taking on this risk by the promise of receiving higher interest on their bonds).

${ }^{106}$ Id. at 379 ("Occasionally, state SPE debt is shown in a separate column [on the state's balance sheet] as indebtedness of the state's 'component units."”).

${ }^{107}$ Id. at 381-83. States have strong economic incentives to stand behind SPE debt. Id. at 318. For example, defaulting on SPE debt could "signal uncertainty as to whether the state will pay its debts generally." Id. Other reasons for states to pay their SPE debt include the important function of SPE operations in supporting government services, honoring a moral obligation, and generally protecting the state's reputation. Id. at 381-82.

${ }^{108}$ Id. at 382 (explaining that the U.S. government supported Fannie Mae and Freddie Mac's debt in order to enhance stability in the housing market). Other U.S. government-sponsored SPEs include, for example, the Tennessee Valley Authority ("TVA"), other "public benefit corporations," and "SPEs used to finance military aircraft." See Steven L. Schwarcz, Direct and Indirect U.S. Government Debt, in Is U.S. GOVERNMENT DEBT DIFFERENT?, supra note 1, at 245, 250-51. In the Housing and Economic Recovery Act, Congress endowed the newly formed Federal Housing Finance Agency ("FHFA") with a variety of mechanisms to strengthen the housing SPEs. See Housing and Economic Recovery Act, 12 U.S.C. § 4511 (2012) (giving the FHFA supervisory and 
Compounding this problem is the reality that if the United States had to step in to support the debt of its states, the amounts at issue could be huge. ${ }^{109}$ Although state finances are generally improving, that improvement ignores the massive amounts of state SPE debt-which, in many states, is much larger than the state's general obligation debt. ${ }^{110}$ If states have to step in to support their SPE debt, the federal government, in turn, may be forced to step in to support the states' debt to keep them from defaulting.

\section{WHAT WOULD BE THE CONSEQUENCES OF A DEFAULT?}

A U.S. debt default would have severe consequences. This Part examines both the legal and economic consequences of a default. First, Section A explains that a default could raise constitutional challenges, based on the Eleventh and Fourteenth Amendments of the U.S. Constitution. ${ }^{111}$ Notwithstanding those challenges, these legal claims would have to overcome several procedural hurdles such as sovereign immunity, the need to establish a remedy, and challenges enforcing a judgment. ${ }^{112}$ Section B then explains how a default would entail severe economic risks for the United States. ${ }^{113}$

regulatory authority over Fannie Mae, Freddie Mac, the Federal Home Loan Banks, and the Office of Finance). Under that authority, the government purchased approximately $\$ 154$ billion of securities issued by Fannie Mae and Freddie Mac to ensure that these SPEs were solvent. The Budgetary Cost of Fannie Mae and Freddie Mac and Options for the Future Federal Role in the Secondary Mortgage Market: Hearing Before the H. Comm. on the Budget, 112th Cong. 7 (2011) (statement of Deborah Lucas, Assistant Director for Financial Analysis, Congressional Budget Office). These purchases were made despite the U.S. government having no legal obligation to repay the debt of Fannie Mae and Freddie Mac. See David Reiss, The Federal Government's Implied Guarantee of Fannie Mae and Freddie Mac's Obligations: Uncle Sam Will Pick Up the Tab, 42 GA. L. ReV. 1019, 1023 (2008) (explaining that "[i]n creating Fannie and Freddie, it appears at first glance that the federal government disavowed any guarantee of the two companies' obligations," but "[d]espite this seemingly clear language, Wall Street believe[d] that the federal government would bail [them] out if they were to become insolvent").

${ }^{109}$ Schwarcz, supra note 102, at 370 ("Virtually all states obtain at least a portion of their public financing through SPEs.”).

${ }^{110}$ Id. (providing the examples of New York, New Jersey, and Virginia, which obtain most of their financing through SPEs).

${ }^{111}$ See infra notes 114-133 and accompanying text.

${ }^{112}$ See infra notes 134-165 and accompanying text.

${ }^{113}$ See infra notes 175-194 and accompanying text. 


\section{A. Legal Consequences}

\section{Constitutional Issues}

Incongruously, although a U.S. debt default is possible, it might not be legal. ${ }^{114}$ Under the Fourteenth Amendment, "The validity of the public debt of the United States ... shall not be questioned.” 115 This provision was originally included in the Constitution to prevent a southern Democratic majority from repudiating Civil War debts. ${ }^{116}$ Despite the provision's history, most believe-and in 1935, in Perry v. United States, the Supreme Court concluded-that it applies generally, not just to Civil War debts. ${ }^{117}$

It remains unclear, however, whether "question[ing]" the "validity" of U.S. debt would include defaulting on such debt. ${ }^{118}$ Some argue that the scope of the Fourteenth Amendment should include that, and that it should even include governmental action that could lead to default. ${ }^{119}$ Others argue, however, that a payment default should not be interpreted as questioning, or repudiating, the validity of U.S. debt. ${ }^{120}$ One leading scholar explained the distinction: "Default is not the same as repudiation. If Congress repudiated the debt, it would be declaring that the debt is not owed. If Congress defaulted on the debt, the [debt] would still be owed; it would simply go (in part) unpaid.",21

On the other hand, a prominent bankruptcy practitioner questions whether the distinction between validity and default is truly meaningful in the context of U.S. government debt: "Obligations of the sovereign can be en-

${ }^{114}$ McConnell, supra note 45, at 49 (explaining that default was most likely constitutional before the Fourteenth Amendment was passed but afterwards is arguably unconstitutional).

${ }^{115}$ U.S. CONST. amend. XIV, § 4.

${ }^{116}$ McConnell, supra note 45, at 49-50.

117294 U.S. 330, 354 (1935). For a brief discussion of Perry, see Michael Abramowicz, Note, Beyond Balanced Budgets, Fourteenth Amendment Style, 33 TULSA L.J. 561, $602-05$ (1997).

${ }^{118}$ See Abramowicz, supra note 117, at 590.

${ }^{119}$ Id. at 590, 592. Under these broad interpretations, courts might have the power to deem U.S. government actions, or inaction, unconstitutional if they pose a threat to creditors. Michael Stern, “Arrest Me. I Question the Validity of the Public Debt," POINT OF ORDER (June 2, 2011, 7:00 AM), http://www.pointoforder.com/2011/06/02/arrest-me-i-question-the-validity-of-the-public-debt/, archived at http://perma.cc/0Zx6HQ6yRk5.

${ }^{120}$ Stern, supra note 119 ("If the framers of the Fourteenth Amendment wanted to say that the government should take no action that would jeopardize the repayment of debt, surely there were more straightforward ways of saying so."); see Jackson, supra note 16, at 60 (stating that "it is not at all clear that the temporary delay of debt service constitutes questioning of the public debt of the sort that the Public Debt Clause proscribed ....”); McConnell, supra note 45, at 50 (differentiating between defaulting on debt and repudiation of debt).

${ }^{121}$ McConnell, supra note 45, at 50. 
forced only at the sovereign's own sufferance, so the validity of the debt and the debt's enforceability merge to become a single concept." ${ }^{122}$

Assuming that a payment default would violate the Fourteenth Amendment, what does that mean for the government's ability to default? If the government does not have money to pay the debt on a timely basis, the constitutionality of default might prove irrelevant. Where the government has no real choice but to violate the Constitution, it may arguably be "freed from constitutional constraint," at least where it did not create the problem leading to the default. ${ }^{123}$ Of course, that begs the question of what constitutes a choice; for example, would the government's decision to default rather than to pay the debt by printing money—at the cost of inflation—be a real choice? ${ }^{124}$ And if it were construed as a real choice, would a court then have the authority to order the government to print the money to avoid default? Would the government even have to comply with that order? These are unresolved questions.

Nonetheless, the Supreme Court's jurisprudence on the constitutionality of state-government debt defaults might help inform the answers. In the midto-late 1800s, several states defaulted, renegotiated, or repudiated their debts despite arguably violating Section 10 of Article I of the Constitution (the "Contract Clause"), which prohibits states from passing any law "impairing the obligation of contracts." 125 Bondholders sued, resulting in a spate of cases that purport to turn on the doctrine of sovereign immunity - the principle that a sovereign cannot be sued without its consent. ${ }^{126}$

${ }^{122}$ Donald S. Bernstein, A Comment on Professor Mooney's Thought Experiment: Can U.S. Debt Be Restructured?, in Is U.S. GovernMENT DEBT DifFERENT?, supra note 1, at 237, 240. Donald Bernstein is a partner and head of the bankruptcy practice of the law firm of Davis, Polk \& Wardwell LLP. Donald S. Bernstein, DAVIS, POLK \& WARDWELL LLP, http://www.davispolk. com/lawyers/donald-bernstein/ (last visited Jan. 15, 2014).

${ }^{123}$ But see Buchanan \& Dorf, supra note 45, at 1218 (arguing that "[w]hile this sentiment is somewhat compelling, it is ultimately wrong”).

${ }^{124}$ See supra notes 76-77 and accompanying text (explaining the risk that printing money could lead to inflation, which could have serious negative consequences for the U.S. economy).

${ }^{125}$ William A. Scott, The Repudiation of State DebTs 4-5 (1969) (explaining the Contract Clause and arguing that Supreme Court decisions clearly show that the Clause applies to contracts involving both states and individuals); Emily D. Johnson \& Ernest A. Young, The Constitutional Law of State Debt, 7 DUKE J. CONST. L. \& PUB. POL'Y 117, 127, 150 (2012) (explaining that when states "delay payments to employees and service providers, they may well find themselves in breach of their contractual obligations" and concluding that "[r]epudiation of a state's bonds is surely unconstitutional under the Contract Clause"); Johnson \& Young, supra at 149 (explaining that most of the states in the former Confederacy repudiated their Reconstructionera debts); see U.S. CONST. art. I, § 10.

${ }^{126}$ Hans v. Louisiana, 134 U.S. 1, 20-21 (1890) (holding that sovereign immunity prevents challenges to state laws repudiating state debt in federal courts); RICHARD H. FALLON, JR., ET AL., HART AND WeChSLER's THE FEDERAL COURTS AND THE FEDERAL SySTEM 992-93 (5th ed. 2003) (describing these cases); Federico Sturzenegger \& Jeromin Zettelmeyer, Has the Legal 
In retrospect though, it appears that sovereign immunity was interpreted and applied on a case-by-case basis depending on the political circumstances surrounding the case. ${ }^{127}$ The Court swung back and forth between finding for bondholders and for states (in the latter case, allowing repudiation and thus arguably sanctioning a constitutional violation), producing a wholly inconsistent body of doctrine. ${ }^{128}$ In these cases, the Court "tended to follow practical necessity; the more dire the financial straits [of a state], the more that zero-sum realities compel[led] protection" of the state via sovereign immunity. ${ }^{129}$ These precedents suggest that when a government is faced with extraordinary debt demands, the Supreme Court might flexibly interpret the Constitution to suit government needs. ${ }^{130}$ Moreover, even if the Supreme Court interpreted the Fourteenth Amendment to require the federal government to print money to avoid default, it is unclear whether the executive branch of the government would have to comply with that order given the Constitution's separation of powers. Further, U.S. presidents have demonstrated a willingness to defy the Supreme Court when they believe necessity demands it. ${ }^{131}$ If the executive branch did not comply, the Fourteenth Amendment would prove irrelevant in a practical sense; there would be no money to collect and the plaintiffs would essentially be left only with a judgment in their favor. ${ }^{132}$ If, for example, a state defaults on $\$ 1$ billion and the debt holders sue and

Threat to Sovereign Debt Restructuring Become Real? 9-10 (Centro de Investigación en Finanzas, Working Paper No. 04/2006, 2006) (explaining sovereign immunity).

127 John J. Gibbons, The Eleventh Amendment and State Sovereign Immunity: A Reinterpretation, 83 Colum. L. REV. 1889, 1974 (1983). In the aftermath of the Civil War, several states moved to repudiate their state debts. Id. Because they may have been willing to ignore Supreme Court interpretations of the Contract Clause that held repudiation to be unconstitutional, the doctrine of sovereign immunity arguably allowed the court to avoid "the humiliation of seeing its political authority compromised.” Id.

${ }^{128} \mathrm{Id}$. at 1996 (explaining the inconsistencies in how the doctrine of sovereign immunity was applied in various states). Compare Sands v. Edmunds, 116 U.S. 585, 585 (1886) (allowing Virginia officers to be sued to enforce a lawyer's right to pay for his license to practice by using a coupon issued by the state of Virginia), and Poindexter v. Greenhow, 114 U.S. 270, 277-78 (1885) (holding that a citizen may sue a state official in Virginia to enforce the state's "Funding Act”), with Hagood v. Southern, 117 U.S. 52, 65, 69 (1886) (holding that individuals may not sue the state to enforce revenue bonds), and Louisiana v. Jumel, 107 U.S. 711, 716, 728 (1883) (holding that Louisiana officers could not be sued in equity to enforce the payment of state bonds).

${ }^{129}$ Ernest A. Young, Its Hour Come Round At Last? State Sovereign Immunity and the Great State Debt Crisis of the Early Twenty-First Century, 35 HARV. J.L. \& PUB. POL'Y 593, 597 (2012).

${ }^{130}$ See id. (explaining that sovereign immunity may be a necessary tool to protect public property and therefore the use of the doctrine reflects "practical necessity").

${ }^{131}$ See infra notes 151-162 and accompanying text.

${ }^{132}$ Felix Salmon, A California Default, REUTERS OpINION (Apr. 24, 2009), http://blogs. reuters.com/felix-salmon/2009/04/24/a-california-default/, archived at http://perma.cc/09fpNvFA DrQ (arguing that challenging the default would be circular). 
win, the state still owes them $\$ 1$ billion-in other words, nothing has changed. ${ }^{133}$

\section{Procedural Hurdles}

Creditors that challenge a U.S. debt default would also face procedural hurdles — including the need to overcome sovereign immunity — to establish a compensable remedy and to enforce any resulting judgment against government assets in the face of executive branch opposition.

The first hurdle, sovereign immunity, is theoretically the lowest hurdle because it can be waived if the sovereign unmistakably expresses its intent to do so. ${ }^{135}$ Currently, many sovereigns include explicit waivers of immunity in their bonds. ${ }^{136}$ The extent to which U.S. debt includes a waiver of sovereign immunity is unclear, though. The statute setting forth procedures for the U.S. government to issue debt securities makes no mention of sovereign immunity, ${ }^{137}$ and correspondence with the U.S. Department of the Treasury suggests that U.S. Treasury securities do not include any waivers of sovereign immunity. $^{138}$

To the extent that U.S. debt does not include an express contractual waiver of sovereign immunity, creditors might turn to the Tucker Act, which grants jurisdiction in certain courts and waives sovereign immunity for nontort monetary claims. ${ }^{139}$ The waiver applies to the federal government's viola-

${ }^{133}$ Id.

${ }^{134}$ See Sturzenegger \& Zettelmeyer, supra note 126, at 11 (explaining that "waivers [of sovereign immunity] are in fact routinely included in bond covenants"). This Article's discussion of procedural hurdles assumes that the default continues long enough for the hurdle to become relevant. For example, if the United States cures a default quickly by paying the amount in arrears, the paid creditor should have no further need to attempt to obtain a judgment against the United States or to enforce any such judgment, if obtained.

${ }^{135}$ FALLON ET AL., supra note 126, at 947 (explaining that "courts have generally insisted that a waiver by Congress be unmistakably expressed”).

${ }^{136}$ Sturzenegger \& Zettelmeyer, supra note 126, at 11. In fact, many creditors demand such waivers. Horacio T. Liendo, III, Sovereign Debt Litigation Problems in the United States: A Proposed Solution, 9 OR. REV. INT'L L. 107, 118-19 (2007). Common waivers of immunity are for jurisdiction, prejudgment attachment, and attachment and execution. Id. at 119.

${ }^{137}$ See 31 U.S.C. § 3121 (2006).

${ }^{138}$ E-mail from Andy Young, Reference Librarian, U.S. Treasury Library, to Paulina Stanfel, Research Assistant to author (Aug. 6, 2013) (on file with author) (stating that based on "a response [that Young] received from a colleague," and cautioning that such response is not legal advice, "Treasury securities, including T-bills, are considered contracts with the government. There is no waiver of sovereign immunity.”).

139 Tucker Act of 1887, 28 U.S.C. §§ 1346(a), 1491 (2006) (governing claims against the United States); see FALLON ET AL., supra note 126, at 961-62 ( "In 1887, the Tucker Act broadened the Court of Claims' jurisdiction to include all 'claims founded upon the Constitution of the United States or any law of Congress ....'”). 
tions of federal statutes, executive regulations, and contracts. ${ }^{140}$ Because U.S. debt securities are arguably a form of debt contract, violating their payment terms by defaulting would likely qualify as a contract violation under the Tucker Act. ${ }^{141}$ Foreign creditors might also be able to take advantage of international treaties under which the United States has waived its sovereign immunity defense or agreed to arbitration stemming from any debt disputes. ${ }^{142}$

The second procedural hurdle to challenging a U.S. debt default is establishing a remedy: unless creditors show they are entitled to an enforceable remedy, "there is no right." 143 The Tucker Act requires plaintiffs to "demonstrate that the ... substantive law relied upon 'can fairly be interpreted as mandating compensation by the Federal Government for damage sustained." "144 The Supreme Court has held that claims based on the Takings Clause of the Fifth Amendment meet this standard because the clause itself prescribes a remedy: just compensation. ${ }^{145}$ Claims based on other constitutional provisions are often rejected, however, because they do not expressly

${ }^{140}$ FALLON ET AL., supra note 126, at 961-62 (“The Tucker Act is strictly limited to claims for money.").

${ }^{141}$ See id. (explaining that the Tucker Act includes claims based in contract law).

${ }^{142}$ See Kevin Gallagher, The New Vulture Culture: Sovereign Debt Restructuring and Trade and Investment Treaties 2 (The IDEAs, Working Paper No. 2/2011, 2011) (explaining that sovereign debt is often an "investment" covered under international investment agreements and arguing that this gives foreign holders of sovereign debt the right to file arbitration claims in accordance with the procedures laid out in such agreements). The U.S. government has effectively provided its consent to be sued under forty-one bilateral investment treaties and several regional treaties, including the North American Fair Trade Agreement and the Dominican Republic-Central America Free Trade Agreement. E-mail from Julie Maupin, Lecturing Fellow, Ctr. for Int'l and Comparative Law, Duke Law School, to author (Aug. 22, 2013) (on file with the author) (explaining that in these treaties, the United States has consented to arbitrate with foreign investors; that these treaties define "investment" quite broadly to include "bonds"; and that international arbitral tribunals have held that sovereign debt is indeed covered by an investment treaty under this type of broad language); see also Ambiente Ufficio S.p.A. v. Argentine Republic, ICSID Case No. ARB/08/09, Decision on Jurisdiction and Admissibility, 384 (Feb. 8, 2013) (explaining that bonds are considered investments under the ICSID definition).

${ }^{143}$ John V. ORTh, The Judicial POWER of the United States: The ElEVEnth AMENDMENT IN AMERICAN HISTORY 5-6 (1987) (explaining that by recognizing sovereign immunity during the Reconstruction era, the Court denied bondholders judicial recognition of their constitutional rights under the Eleventh Amendment and allowed states to repudiate their debts); see FALLON ET AL., supra note 126, at 938 (explaining that the availability of certain forms of relief is closely connected to whether Congress has waived sovereign immunity).

${ }^{144}$ United States v. Mitchell, 463 U.S. 206, 216-17 (1983) (quoting United States v. Testan, 424 U.S. 392, 400 (1976)).

${ }^{145}$ U.S. CONST. amend. V; FALLON ET AL., supra note 126, at 962 (citing United States v. Causby, 328 U.S. 256 (1946)); see Gregory C. Sisk, A Primer on the Doctrine of Federal Sovereign Immunity, 58 OKLA. L. REV. 439, 449 (2005) (explaining the Takings Clause). 
provide for a monetary remedy. ${ }^{146}$ It is therefore uncertain that creditors asserting a Fourteenth Amendment challenge to a U.S. debt default would clear this hurdle because the Fourteenth Amendment does not explicitly provide for a monetary remedy. ${ }^{147}$

The last procedural hurdle is enforcing a judgment, if one is actually obtained. For foreign creditors, it is generally difficult to force a reluctant government to pay because most sovereign assets and income streams are located inside the defaulting country. ${ }^{148}$ To the extent the United States has assets outside its jurisdictional boundaries, however, foreign creditors might be able to legally seize those assets to pay certain international arbitration awards. ${ }^{149}$

Even domestic creditors could face enforcement problems. If the federal government defaulted because it did not have funds to pay the debt, the only other source of payment would likely be in the form of non-cash government assets. If these assets were important to government operations, the executive branch would likely try to defy the Court's judgment. ${ }^{150}$

For example, during the Supreme Court's deliberations in Perry v. United States in 1935, President Franklin Roosevelt announced he would disobey

${ }^{146}$ FALLON ET AL., supra note 126, at 962 (explaining that claims based on the First Amendment, the Due Process Clause of the Fourteen Amendment, the Sixth Amendment's right to counsel, and the Eight Amendment's Cruel and Unusual Punishment Clause have all been rejected under the Tucker Act). Similarly, courts have rejected requests for specific performance compelling the government to make payments in compliance with contracts because the Tucker Act impliedly excludes contractual remedies other than monetary damages. Id. at 969.

${ }^{147}$ As a litigation strategy, such creditors might try to frame their remedy as "just compensation" under the Takings Clause of the Fifth Amendment for government breach of payment in violation of the Fourteenth Amendment.

${ }^{148}$ Sturzenegger \& Zettelmeyer, supra note 126, at 2 (explaining that “a sovereign cannot credibly commit to hand over assets within its borders in the event of a default"); see Lawrence Lokken, A Tax Lawyer's Observations on Scary Numbers, Politics, and Irresponsibility: A Commentary on Shaviro's Reckless Disregard, 45 B.C. L. REV. 1335, 1340 (2004) (explaining that foreign ownership of U.S. debt is increasing).

${ }^{149}$ See Convention on the Settlement of Investment Disputes Between States and Nationals of Other States, art. 53, opened for signature Mar. 18, 1965, 17 U.S.T. 1270, 575 U.N.T.S. 159 [hereinafter "ICSID Convention"]; Convention on the Recognition and Enforcement of Foreign Arbitral Awards, art. 4, Jun. 10, 1958, 21 U.S.T. 2517, 330 U.N.T.S. 38 [hereinafter "New York Convention"]. If those foreign creditors are nationals of states that are party to the International Centre for Settlement of Investment Disputes (“ICSID”) Convention, which has over 140 member states, including the United States, Article 53 of the ICSID Convention might allow arbitral awards to be enforced against member-state assets. E-mail from Maupin, supra note 142. Additionally, Article V of the New York Convention, which has 146 signatory states, including the United States, allows the holder of a valid arbitration award to request enforcement of the award from the courts of any signatory state. Id. Those courts must enforce the award, including by attachment of assets of a contracting state, unless one of a handful of narrow exceptions is met. Id.

${ }^{150}$ See infra notes 151-162 and accompanying text (explaining that past presidents have demonstrated a willingness to ignore the Court). 
the Court if it delivered an unfavorable opinion. ${ }^{151}$ In that case, the executive branch of the federal government refused to redeem its bonds in gold, as promised in the bond contracts, arguing that a June 5, 1933 joint resolution of Congress abrogated that promise. ${ }^{152}$ The bondholder-plaintiffs claimed that the joint resolution was unconstitutional because it deprived them of property without due process of law. ${ }^{153}$ President Roosevelt believed that having to redeem U.S. bonds in gold would lead to economic catastrophe. ${ }^{154}$ Anticipating a decision requiring such redemption, Roosevelt drafted a fireside chat, an evening radio address appealing directly to the people, announcing his intention not to comply with the Court's ruling. ${ }^{155}$ The basis of his address was a necessity argument, using the Bible and the Golden Rule for support. ${ }^{156}$ The address was ultimately unnecessary because the Perry court decided in his favor, but Roosevelt's readiness to defy the Court was clear. ${ }^{157}$

Other presidents have shown a similar willingness to defy judicial orders. President Andrew Jackson, for example, reportedly responded to a Supreme Court mandate with the now famous line, "John Marshall has made his decision, now let him enforce it." ${ }^{\text {"158 }}$ President Abraham Lincoln followed suit in the 1861 Circuit Court for the District of Maryland case of Ex parte Merryman. ${ }^{159}$ In order to protect Washington, D.C. against secessionist forces, Lincoln suspended the privilege of the writ of habeas corpus. ${ }^{160}$ Chief Justice Roger Taney, then acting as circuit judge, declared the suspension unlawful. ${ }^{161}$ Lincoln refused to respect the decision, arguing in part that the President may violate a single law if it is done in order to preserve the Constitution

${ }^{151}$ Gerard N. Magliocca, The Gold Clause Cases and Constitutional Necessity, 64 FLA. L. REV. 1243, 1258 (2012).

${ }^{152}$ Perry, 294 U.S. at 347-48.

${ }^{153}$ Id. at 347.

${ }^{154}$ Magliocca, supra note 151, at 1247.

${ }^{155}$ Id. at 1262. President Roosevelt planned to ignore such a decision until Congress passed a statute invoking sovereign immunity to bar further bondholder suits. Id. at 1261 .

${ }^{156}$ Id. at $1273-74$.

${ }^{157}$ The Court determined that although the Joint Resolution was unconstitutional, the bondholders were not entitled to relief. Magliocca, supra note 151, at 1246.

${ }^{158}$ Richard H. Fallon, Jr., Executive Power and the Political Constitution, 2007 UTAH L. REV. 1, 8-9 (explaining that President Jackson's statement referred to "the Supreme Court's decree in Worchester v. Georgia, which ordered the State of Georgia to release a prisoner on the ground that his detention violated a federal treaty").

${ }^{159}$ Id. at 2-3 (citing Ex parte Merryman, 17 F. Cas. 144 (C.C.D. Md. 1861) (No. 9487)).

${ }^{160}$ Michael Stokes Paulsen, The Merryman Power and the Dilemma of Autonomous Executive Branch Interpretation, 15 CARDOZO L. REV. 81, 89-90 (1993) (explaining Ex parte Merryman).

${ }^{161}$ Id. at 90 . 
as a whole—in essence, Lincoln was making a necessity argument, not unlike Roosevelt's. ${ }^{162}$

Notwithstanding these precedents, it is unclear whether the executive branch has the legal authority to defy orders of the judicial branch. Some argue that the executive branch must comply with such orders. ${ }^{163}$ Others contend that each branch of the U.S. government can determine for itself what is constitutional, making judicial rulings not automatically binding on the executive. ${ }^{164}$ In the event of a true deadlock between the judicial and executive branches, the ultimate arbiter might end up being the legislative branch, in which case Congress would have to decide whether it is prepared to impeach the President for defying the judicial order. ${ }^{165}$

\section{Other Legal Consequences}

Depending on the contractual terms of particular U.S. debt securities, there might be additional legal consequences. For example, sovereign debt securities sometimes include cross-default clauses, under which a default by the sovereign on virtually any of its debt securities can trigger a default on other debt securities of the sovereign that include a cross-default clause. ${ }^{166}$ Investors in those other debt securities can then accelerate the maturities of their debt, even if those other debt securities have been current in payment. ${ }^{167}$ As a result, the sovereign can find huge amounts of its debt coming due unexpectedly as a result of its default—possibly even its temporary default—on a relatively small amount of debt. ${ }^{168}$ Even if the sovereign subsequently cures

${ }^{162}$ Fallon, supra note 158, at 3; Paulsen, supra note 160, at 94; see supra note 156 and accompanying text (explaining President Roosevelt's argument).

${ }^{163}$ Fallon, supra note 158, at 11 (calling this the "Pure Judicial Supremacy Model”).

${ }^{164}$ Id. at 14 ("According to the Political Constitutional Model, each of the three branches of the national government gets to determine for itself what the Constitution means.”).

${ }^{165}$ Id. at 22-23 (arguing that Congress would likely impeach the President if he defied a judicial order but that nevertheless the President could decide to "take his or her chances").

${ }^{166}$ Stephen J. Choi et al., The Evolution of Contractual Terms in Sovereign Bonds, J. LEG. ANALYSIS, Spring 2012, at 131, 140 (describing cross-default clauses as a "common method investors [in sovereign bonds] use to protect themselves").

${ }^{167} I d$. (emphasizing that cross-default clauses "provide that if the sovereign defaults on some of its debt, then that action constitutes a default on other debt even though the sovereign is otherwise current on that debt").

${ }^{168}$ See id. In the author's experience, the ability of creditors to use a cross-default clause to accelerate the maturity of their debt securities depends on the precise terms of the clause. A crossdefault clause may enable acceleration if the default on other debt continues past any applicable grace period or exceeds a minimal threshold amount. See id. at 147 (describing a grace period of thirty days). 
that default by paying the amount originally in arrears, ${ }^{169}$ that cure would not necessarily rescind the acceleration of the other debt. ${ }^{170}$

It is unclear whether any U.S. debt securities currently include crossdefault clauses. ${ }^{171}$ The statute setting forth procedures for the U.S. government to issue debt securities makes no mention of these types of clauses, ${ }^{172}$ thereby leaving their inclusion subject to the discretion of the Secretary of the Treasury. ${ }^{173}$ Even if no U.S. debt securities currently include cross-default clauses, such clauses could be included in future issuances of securities, perhaps at the demand of investors. ${ }^{174}$ If any U.S. debt securities were to include cross-default clauses, the consequences of a U.S. debt default could be greatly magnified.

\section{B. Economic Consequences}

A U.S. debt default ${ }^{175}$ would also have both microeconomic and macroeconomic, or systemic, consequences. ${ }^{176}$ Observers have argued that a default would likely result in stocks, bonds, and the dollar "plummet[ing] in the im-

${ }^{169}$ Cf. supra note 134 and accompanying text (discussing that the United States could cure a default by paying the amount in arrears).

${ }^{170}$ This observation is based on the author's experience. Cf. Choi et al., supra note 166, at 147-48 (observing that although acceleration provisions "vary a great deal," the vote of some majority of creditors may be able to "reverse the acceleration").

${ }^{171}$ It is also unclear whether any U.S. debt securities currently allow investors to accelerate the maturities of their debt. If any U.S. debt securities did contain cross-default clauses, however, it would be customary, in the author's experience, for those securities to also allow investors therein to accelerate the maturities of their debt; otherwise, a breach of the cross-default clause would create a right without a remedy.

${ }^{172}$ See 31 U.S.C. $\S 3121$ (2006).

${ }^{173}$ Compare 31 U.S.C. § 3121(a) (providing that in issuing debt obligations of the United States, "the Secretary of the Treasury may prescribe ... other conditions"), with 31 U.S.C. $\S 3121$ (e) (providing that any "decision of the Secretary [of the Treasury] about an issue of [debt] obligations under sections 3102-3104 of this title is final").

${ }^{174}$ Cf. supra note 166 and accompanying text (describing cross-default clauses as a "common method investors [in sovereign bonds] use to protect themselves”).

${ }^{175}$ Recall that this Article uses the term "default" to mean a hard default: non-payment of debt when due, or a distressed exchange offer. See supra note 16 and accompanying text.

${ }^{176}$ Cf. Schwarcz, supra note 99, at 817-18. In a previous article written by this author, I described the difference between microeconomic and macroeconomic consequences:

The primary goal for regulating financial risk is micro-prudential: maximizing economic efficiency within the financial system. Systemic risk is a form of financial risk, so efficiency should certainly be a goal in its regulation. But systemic risk also represents risk to the financial system itself. Any framework for regulating systemic risk therefore should also include that macro-prudential goal: protecting the financial system itself.

Id. 
mediate aftermath." ${ }^{177}$ Credit markets would likely freeze, harming both companies and consumers. ${ }^{178}$ The downgrading of credit ratings on U.S. debt would also make it much more difficult and expensive for the country to borrow. ${ }^{179}$

Even a mere "technical" default, caused by illiquidity, could harm the real economy. ${ }^{180}$ The 1979 debt defaults, which were temporarily caused by a federal debt ceiling limit on new borrowings, ${ }^{181}$ resulted in a sixty basis point increase in the interest rate on Treasury bills, ${ }^{182}$ an increase that might well be permanent. ${ }^{183}$ Such a rate increase could also increase the cost of private borrowings. Former Treasury Secretary Timothy Geithner has observed, for ex-

${ }^{177}$ Matthew Craft, U.S. Default Would Likely Cause Stocks, Bonds, Dollar to Collapse, HuFFINGTON POST (July 17, 2011, 4:14 PM), http://www.huffingtonpost.com/2011/07/17/us-defaultmarkets-consequences_n_901070.html, archived at http://perma.cc/SX73-LGEU.

${ }^{178}$ Id.; see Beth Kobliner, How Would a U.S. Default Affect Consumers?, HufFINGTON POST (Jan. 29, 2011, 1:10 PM), http://www.huffingtonpost.com/beth-kobliner/us-default-consumers_b_ 912830.html, archived at http://perma.cc/4HTZ-9SV6 (explaining the practical effects that a consumer would feel if the government defaulted).

${ }^{179}$ Craft, supra note 177 (explaining that "U.S. Treasury yields act like a floor for other lending rates, so raising them makes it more expensive for Americans to take out mortgages”); Ian Talley, Bernanke Warns on Debt-Limit 'Chaos,' WALL ST. J. BlOGS (Mar. 1, 2011, 2:30 PM), http:// blogs.wsj.com/economics/2011/03/01/bernanke-warns-on-debt-limit-chaos/, archived at http://perma. cc/B5UA-JYRN (quoting Federal Reserve Chairman Ben Bernanke as saying: "For a long time [after a default], the U.S. would have to pay higher interest rates in the market and that would make our deficit problems even more intractable.”). Although the accompanying depreciation of the dollar would improve global price competitiveness of U.S. goods and services, thereby increasing net exports and decreasing U.S. net external debt, the negative impacts of currency depreciation, such as decreasing international purchasing power in conjunction with higher borrowing costs, would overshadow any excess revenue from export increases. See CRAIG K. ELWELL, CONG. RESEARCH SERV., RL34582, THE DEPRECIATING DOLLAR: ECONOMIC EFFECTS AND POLICY RESPONSE 9-12 (2012); Jonathan Masters, U.S. Debt Ceiling: Costs and Consequences, COUNCIL ON FOREIGN REL., http:// www.cfr.org/international-finance/us-debt-ceiling-costs-consequences/p24751\#p7, archived at http:// perma.cc/WJ6N-MB83 (last updated Oct. 4, 2013) (explaining how a U.S. default could cause the dollar's value to decline).

${ }^{180}$ See Belton et al., supra note 18, at 1 (defining a technical default as a delay in payment that "is quite short-term (less than a few days)"); infra note 189 and accompanying text (explaining that investors depend not only on ultimate payment in full but also on timely payment when due, and indeed credit-rating agencies take both factors into account and even a temporary delay in payment is regarded as an actual default).

${ }^{181}$ See supra notes 48-49 and accompanying text (explaining the 1979 defaults). The defaulted amounts in 1979 were also relatively small. Zivney \& Marcus, supra note 48, at 476 (estimating that there were about $\$ 122$ million defaulted T-bills in May 1979).

${ }^{182}$ When Did the U.S. Last Default on Treasury Bonds?, NAT'L PUB. RADIO (July 11, 2011, 3:00 PM), http://www.npr.org/2011/07/11/137773341/looking-at-when-the-u-s-last-defaulted-ontreasury-bond, archived at http://perma.cc/467J-F4ST (estimating these defaults resulted in billions of dollars in increased borrowing costs in 1997 (citing Zivney \& Marcus, supra note 48)).

${ }^{183}$ Zivney \& Marcus, supra note 48, at 487 (concluding that "the series of defaults [in 1979] resulted in a permanent increase in interest rates of about 60 basis points”). 
ample, that a U.S. debt default would "raise all borrowing costs" because "US Treasuries set the benchmark borrowing rate" for private loans. ${ }^{184}$

Investment bank J.P. Morgan recently issued a report updating the potential economic impact of a technical default. The report assumes that the United States temporarily misses an interest or principal payment on its debt. ${ }^{185}$ Even if this temporary default does not reflect an actual deterioration of U.S. solvency, it still would "almost certainly have large systemic effects with long-term adverse consequences for Treasury finances and the US economy." "186 At a minimum, the United States would likely see a one percent reduction in gross domestic product due to higher interest rates and a likely equity selloff. ${ }^{187}$ Even worse, the report concluded that the default also "could leave lasting damage in its wake due to a permanent decline in foreign demand [for U.S. Treasury securities], which will likely lead to [continuing] higher borrowing costs and larger deficits."

A technical default could also impair the credit rating on U.S. debt securities. Credit-rating agencies like Standard \& Poor's and Moody's assign sovereign-debt ratings based not only on the government's ability to pay its debt

${ }^{184}$ William W. Bratton, A World Without Treasuries?, in Is U.S. GOVERNMENT DEBT DIFFERENT?, supra note 1, at 13, 13 (citing Letter from Timothy Geithner, U.S. Treasury Sec'y, to Harry Reid, Majority Leader, U.S. Senate (Jan. 6, 2011), available at http://www.treasury.gov/ connect/blog/Pages/letter.aspx, archived at http://perma.cc/F8J6-ZY8U). The U.S. Department of the Treasury reiterated this observation in its report cautioning about the potential impact of a U.S. debt default due to Congress's failure to raise the federal debt ceiling. See U.S. DEP'T OF TREAS., The Potential Macroeconomic EFfect of DebT CeiLing Brinksmanship 4-5 (2013) (explaining that " $[w] i t h$ Treasury yields rising this year, a widening in spreads would lead to an increase in yields on corporate debt," and would similarly "increase mortgage rates, raising the cost of buying a home").

${ }^{185}$ Belton et al., supra note 18 , at 1.

${ }^{186}$ Id.; see also supra notes 24-25 and accompanying text (observing that even an otherwise temporary U.S. debt default could undermine the nation's perceived creditworthiness, making it more expensive or difficult to borrow in order to repay future maturing debt and therefore increasing rollover risk and potentially triggering a larger debt crisis). The recent Department of Treasury report was even more blunt than this, as it stated that "[i]n the event that a debt limit impasse were to lead to a default, it could have a catastrophic effect on not just financial markets but also on job creation, consumer spending and economic growth ....” U.S. DEP'T OF TREAS., supra note 184, at 6.

${ }^{187}$ Belton et al., supra note 18, at 6 (suggesting that, aside from gross domestic product "the ultimate damage [to the economy] could be far greater").

${ }^{188}$ Id. at 4; cf. The Mother of All Tail Risks, ECONOMIST, June 25, 2011, at 83, $83-84$ (estimating that a temporary U.S. debt default today could cost the U.S. government approximately $\$ 86$ billion yearly; observing that foreign investors have shown a newfound willingness to diversify their holdings; and discussing indirect effects of a U.S. debt default, such as impairing the use of Treasury securities as collateral in the repo and derivatives markets). The prediction of a permanent decline in foreign demand for U.S. Treasury securities reflects J.P. Morgan's internal research showing that foreign investors would react much more negatively than U.S. domestic investors to a technical default. Belton et al, supra note 18, at 5. 
in full, but also on its ability and willingness to pay its debt on time. ${ }^{189}$ The ratings decision therefore normally includes an examination of the sovereign's past payment performance. ${ }^{190}$ Thus, during the 2011 federal debt ceiling crisis, Moody's commented that “[a]n actual default, regardless of duration, would fundamentally alter Moody's assessment of the timeliness of future payments, and a Aaa rating would likely no longer be appropriate [for U.S. debt]." ${ }^{191}$ If both Standard \& Poor's and Moody's reduced their ratings on U.S. debt securities, the nation's borrowing costs would almost certainly increase significantly. ${ }^{192}$

The discussion so far has examined the economic consequences of an actual, albeit temporary, U.S. debt default. The mere threat of such a debt default, however, might also raise borrowing costs. A 2012 U.S. Government Accountability Office (GAO) report found, for example, that the 2011 federal debt ceiling crisis caused Treasury borrowing costs to increase by $\$ 1.3$ billion for the fiscal year of 2011 alone. ${ }^{193}$ According to the report, delays in raising the debt ceiling caused investors to view Treasury securities as riskier, and thus they demanded a higher interest rate. ${ }^{194}$

\section{How Could the Consequences of A Default Be Mitigated?}

Given the serious consequences of a U.S. debt default, it is important to examine how to mitigate those consequences. The analysis below first considers a debt restructuring. Although a bilateral, or consensual, restructuring could theoretically avoid a default or mitigate its consequences, it likely

189 STANDARD \& POOR's, HOw WE RATE SOVEREIGNS 3 (2012), available at http://www. standardandpoors.com/spf/ratings/How_We_Rate_Sovereigns_3_13_12.pdf, archived at http://perma. cc/C5CU-4KTJ (explaining the criteria used to produce credit ratings); Ratings Policy \& Approach, MoODY's, http:/www.moodys.com/Pages/amr002003.aspx, archived at http://perma.cc/TM3Z-LW2P (last visited Nov. 24, 2013) (same).

190 See STANDARD \& POOR's, supra note 189, at 3.

191 Moody’s Investors Service, Announcement: Moody’s Places US Aaa Government Bond Rating and Related Ratings on Review for Possible Downgrade, MoODY's, July 13, 2011, https:// www.moodys.com/research/Moodys-Places-US-Aaa-Government-Bond-Rating-and-Related-RatingsPR_221800, archived at http://perma.cc/PXU9-6C23.

192 See Carmen M. Reinhart, Default, Currency Crises, and Sovereign Credit Ratings, WORLD BANK ECON. REV., Aug. 2002, at 151, 151 ("Credit ratings have been shown to have a significant impact on the yield spreads of sovereign bonds.”).

193 U.S. GOV’T ACCOUNTABILITY OFFICE, GAO-12-701, DEBT LIMIT: ANALYSIS OF 2011-2012 ACTIONS TAKEN AND EFFECT OF DELAYED INCREASE ON BORROWING COSTS 21-22 (2012).

${ }^{194}$ Id.; $c f$. Belton et al., supra note 18, at 2 (observing that investors will "undertake riskmanagement actions in preparation for a potential Treasury default”). Additionally, if investors view Treasury securities as risky, regulators might want firms that use Treasuries to comply with capital requirements to value such securities at a discount. $C f$. id. (discussing how rising yields could impact net asset values). 
would take too long to be effective. ${ }^{195}$ A unilateral debt restructuring could be implemented quickly, but it too would likely fail to mitigate consequences because it is tantamount to a default. ${ }^{196}$ The analysis also considers a debt bailout, arguing that although the IMF might have the economic wherewithal to bail out the United States, the conditionality imposed by the IMF as a quid pro quo would likely be politically unacceptable to the United States. ${ }^{197}$

\section{A. Debt Restructuring}

A U.S. debt default could be avoided by restructuring the debt prior to actual default, enabling the government to repay the debt as it comes due. ${ }^{198}$ The consequences of such a default might also be mitigated if the debt were restructured after default. ${ }^{199}$

It is essential that any method of restructuring U.S. debt be speedy. This is because if done to avoid default, the restructuring would have to be in place before the debt matures. ${ }^{200}$ And if done to mitigate the consequences of a default, time would be of the essence in order to minimize financial chaos. ${ }^{201}$ Debt restructuring therefore could not be a complete solution to rollover risk, especially if the illiquidity is recognized at the last moment, because it is unlikely that it could be completed within the requisite timeframe. ${ }^{202}$

In a non-U.S. context, bilateral restructuring of sovereign debt would be an option. ${ }^{203}$ But bilateral approaches-meaning debt restructuring that

${ }^{195}$ See infra notes 203-204 and accompanying text (explaining the consequences of a bilateral restructuring of U.S. debt).

${ }^{196}$ See infra notes 205-212 and accompanying text (explaining the consequences of a unilateral restructuring of U.S. debt).

${ }^{197}$ See infra notes 213-232 and accompanying text (considering the implications of a bailout).

${ }^{198}$ See Charles W. Mooney, Jr., United States Sovereign Debt: A Thought Experiment on Default and Restructuring, in Is U.S. GOVERNMENT DEBT DIFFERENT?, supra note 1, at 169, 234 (explaining that restructuring means reducing the debt through legal channels and through "selective intentional default" on some of the debt). Say, for example, that $\$ 100$ billion of debt is coming due on a certain date ("Date 1"), when the government will only have $\$ 75$ billion in funds, but the government expects to have an additional \$25 billion in funds by a later date ("Date 2"). A debt default could be avoided by restructuring the debt prior to Date 1 so that (for simplicity, ignoring the time value of money) only \$75 billion comes due on Date 1 and the remaining \$25 billion comes due on or after Date 2.

${ }^{199}$ Cf. Bernstein, supra note 122, at 242 (suggesting that the United States could spread its costs among stakeholders in restructuring).

${ }^{200}$ See supra note 198 (highlighting the importance of a timely restructuring of the debt).

${ }^{201}$ Bernstein, supra note 122, at 237.

${ }^{202}$ The failure of word-processing equipment used to prepare check schedules might, for example, cause that last moment recognition that the country is illiquid. See supra note 49.

${ }^{203}$ See generally Steven L. Schwarcz, "Idiot's Guide” to Sovereign Debt Restructuring, 53 EMORY L. J. 1189 (2004) [hereinafter Idiot's Guide] (discussing the different approaches to sovereign debt restructuring); Steven L. Schwarcz, Sovereign Debt Restructuring: A Bankruptcy Reorgan- 
achieves the consent of both the debtor-nation and its creditors-would not necessarily be speedy, nor are they intended to address the uniquely chaotic problem of a U.S. sovereign debt default. ${ }^{204}$

The United States could attempt to unilaterally restructure its debt. Argentina unilaterally restructured its debt in 2001, and Russia did it in $1998 .^{205}$ But to do so would effectively amount to the United States refusing to pay national debt while dictating to creditors new payment terms. ${ }^{206}$ That is close enough to a debt repudiation to be certain to generate numerous Fourteenth Amendment lawsuits. ${ }^{207}$ Indeed, any sovereign unilateral debt restructuring tends to generate multiple lawsuits, even absent constitutional issues. ${ }^{208} \mathrm{~A}$ U.S. unilateral debt restructuring would likely also spark the filing of arbitration claims against the United States, under international treaties. ${ }^{209}$

Furthermore, unilateral debt restructuring - even if the government merely delays when payments are to be made, as opposed to writing off portions of its debt-is tantamount to a default because creditors are not paid on a timely basis according to their original contractual terms. ${ }^{210}$ That could create the same risk of systemic contagion as a default that is not cloaked in debt-restructuring language. ${ }^{211}$ Unilateral debt restructurings could also end up being costly to the government imposing them by increasing the price of future borrowing. For example, Argentine sovereign bond spreads rose 6000

ization Approach, 85 CORNELL L. REV. 956 (2000) (discussing at length how national debt in a nonU.S. context could and should be bilaterally restructured); Steven L. Schwarcz, Sovereign Debt Restructuring Options: An Analytical Comparison, 2 HARV. BuS. L. REV. 95 (2012) [hereinafter Sovereign Debt Restructuring Options] (discussing debt restructuring alternatives to bailouts).

${ }^{204}$ See Mooney, supra note 198, at 234 (evaluating the "feasibility of any type of restructuring of U.S. sovereign debt that would involve a material haircut (legal or de facto) of U.S. obligations").

${ }^{205}$ Sovereign Debt Restructuring Options, supra note 203, at 101 n.39, 111.

${ }^{206}$ See Anna Gelpern, What Bond Markets Can Learn from Argentina, INT’L FIN. L. REV., Apr. 2005, at 19, 20 (explaining how Argentina restructured its debt by changing the terms of existing obligations).

207 See supra notes 114-124 (explaining how the Fourteenth Amendment imposes limits on the U.S. government's ability to repudiate its debt).

${ }^{208}$ Cf. Gelpern, supra note 206, at 21 (noting that Argentina faced thousands of lawsuits, including dozens in New York and over a hundred in Europe, during and after its unilateral debt restructuring).

${ }^{209}$ E-mail from Maupin, supra note 142 (providing examples of treaties that might require the United States to arbitrate debt disputes); see supra notes 148-149 and accompanying text (observing that foreign creditors might be able to legally seize U.S. assets to pay certain international arbitration awards).

${ }^{210}$ Cf. Gelpern, supra note 206, at 20 (explaining that in its unilateral restructuring, Argentina "pushed off maturities on over $\$ 30$ billion" and "swap[ped] about $\$ 42$ billion in foreign bonds for loans paying much lower interest rates").

${ }^{211}$ Cf. supra note 16 (characterizing a distressed, or non-consensual, exchange offer as a type of hard default). 
basis points after Argentina's 2001 announcement that it would unilaterally restructure its debt. ${ }^{212}$

\section{B. Bailout}

By definition, a bailout could mitigate the consequences of a U.S. debt default. But there likely is only one institution that might have the economic wherewithal to bail out the United States: the IMF. ${ }^{213}$ Conceived at a United Nations conference at the close of World War II, the IMF was created to foster global economic cooperation and to avoid a repetition of the Great Depression. ${ }^{214}$ With 188 member nations, the IMF can help to bail out its members by lending them money. ${ }^{215}$ Although these loans historically have gone to developing, rather than developed, countries, ${ }^{216}$ nations like Greece, Portugal, and Ireland have recently turned to the IMF for help. ${ }^{217}$

As a condition of lending, the IMF customarily requires certain reform measures. ${ }^{218}$ Such “conditionality" can include, for example, austerity measures such as controlling budget revenues and restructuring the nation's banks. ${ }^{219}$ By accepting IMF money with its conditionality, a country thus for-

212 Sovereign Debt Restructuring Options, supra note 203, at 111. There was, however, little systemic contagion from Argentina's unilateral debt restructuring, probably because Argentina's economy was neither significant nor interconnected enough to the larger world economy. $C f$. Fin. STABILITY BD., REDUCING THE MORAL HAZARD POSED BY SYSTEMICALly IMPORTANT FINANCIAL INSTITUTIONS 1 (2010), available at http://www.financialstabilityboard.org/publications/r_ 101111a.pdf, archived at http://perma.cc/3J56-NGP3 (designating size and interconnectedness as two of the three most important criteria for assessing the systemic riskiness of financial institutions).

${ }^{213}$ See IMF's Financial Resources and Liquidity Position, January 2011-January 2013, INT'L MONETARY FUND, http://www.imf.org/external/np/tre/liquid/2013/0113.htm, archived at http://perma.cc/LRB2-MTEL (last visited Jan. 17, 2014) (explaining that as of January 2013, the IMF had total usable resources of $\$ 556$ billion).

${ }^{214}$ What We Do, INT'L MONETARY FUND, http://www.imf.org/external/about/whatwedo.htm, archived at http://perma.cc/9WTX-7SVU (last visited Jan. 17, 2014).

${ }^{215}$ Id. An IMF bailout would therefore be unlikely to help the United States avoid default due to Congress's failure to raise the federal debt ceiling, since the government would not have authority to borrow from the IMF, at least on a full-faith-and-credit basis. See supra notes 43-45 and accompanying text (explaining that if Congress failed to raise the debt ceiling, the President would not have the Constitutional authority to borrow more money).

${ }^{216}$ Brock Blomberg \& J. Lawrence Broz, The Political Economy of IMF Voting Power 1 (Nov. 10, 2006) (unpublished manuscript), available at http://www.princeton.edu/ pcglobal/ conferences/IPES/papers/broz_blomberg_F1030_1.pdf, archived at http://perma.cc/5UUH-4CW8.

${ }^{217} 41$ IMF Bailouts and Counting-How Long Before the Entire System Collapses?, SILVER DOCTORS (July 8, 2013), http://www.silverdoctors.com/41-imf-bailouts-and-counting-how-longbefore-the-entire-system-collapses, archived at http://perma.cc/4Z9G-TV9K.

${ }^{218}$ Ugo Panizza et al., The Economics and Law of Sovereign Debt and Default, 47 J. ECON. LITERATURE 651, 671 (2009).

${ }^{219}$ Elmar Koch \& Iikka Korhonen, The Aftermath of the Russian Debt Crisis, BANK OF FINLAND INST. FOR ECONOMIES IN TRANSITION ONLINE 1, 10 (2000), available at http://www. 
feits a measure of control over its economy. ${ }^{220}$ Politically, it is far from clear that the United States would accept that, even if faced with default. ${ }^{221}$

If, however, the IMF were to offer a bailout that the United States accepts, it could help to alleviate U.S. debt problems. ${ }^{222}$ If the bailout occurs quickly enough, it could help prevent the debt default; and even if a default occurs, a bailout could provide the United States with stability ${ }^{223}$ by allowing it to pay its defaulted creditors. ${ }^{224}$ In addition, the announcement of a bailout tends to positively affect domestic stock prices, possibly reducing the threat posed by systemic risk. ${ }^{225}$ If the terms of an IMF bailout were more lenient, ${ }^{226}$ it might also provide the United States with an opportunity to improve

suomenpankki.fi/bofit/tutkimus/tutkimusjulkaisut/online/documents/bon0700.pdf, archived at http:// perma.cc/3WAF-TU76.

${ }^{220}$ Johnson \& Young, supra note 125, at 139 (explaining that examples of IMF conditionality requirements include "currency devaluation, industry privatization, trade liberalization, spending cuts on social services, required deficit reduction, and promotion of exports").

${ }^{221}$ This Article does not purport to address whether the U.S. government's sizeable role in the IMF might reduce IMF-imposed conditionality. For example, the IMF's governance structure ties a member country's voting power to the size of its monetary contribution. Blomberg \& Broz, supra note 216, at 1 . As a result, the United States has $16.75 \%$ of the vote, whereas the second largest contributor, Japan, has only 6.23\%. IMF Members' Quotas and Voting Power, and IMF Board of Governors, INT'L MONETARY FUND, http://www.imf.org/external/np/sec/memdir/members.aspx\#J, archived at http://perma.cc/FK94-R482 (last updated Nov. 17, 2013); see Bailouts Go InternationalThe IMF, the U.S., and the Fiscal Crisis, GOP.GOv (May 7, 2010), http://www.gop.gov/policynews/10/05/07/bailouts-go-international-the, archived at http://perma.cc/3K3K-9N55 (providing data on the percentage of funding quota and percentage of votes for several IMF member nations). The United States therefore has significant influence over IMF policies and decisions. Ngaire Woods, The United States and the International Financial Institutions: Power and Influence Within the World Bank and the IMF, in US HEGEMONY AND INTERNATIONAL ORGANIZATIONS 94, 94 (Rosemary Foot et al. eds., 2003) (explaining that the voting power of the United States as well as its role in determining the "structure, location, and mandate" of the IMF and the World Bank means that the "United States enjoys a special position" in these institutions).

${ }^{222}$ Cf. Johnson \& Young, supra note 125, at 120 (proposing a bailout as a possible solution in a situation where a state, such as California, defaulted).

${ }^{223}$ See supra notes 17-18, 180 and accompanying text (differentiating technical defaults due to illiquidity from defaults due to insolvency). Stability would be an important consideration if the United States went into default because of insolvency. See supra notes 17-18, 180 and accompanying text.

${ }^{224}$ See Charles W. Calomiris, The IMF's Imprudent Role as Lender of Last Resort, 17 CATO J. 275, 275-76 (1998) (arguing that bailouts are misguided because they contradict the fundamental principal that in a free market, risk is allocated to those that undertake risky decision making).

${ }^{225}$ See Sie Ting Lau \& Thomas H. McInish, IMF Bailouts, Contagion Effects, and Bank Security Returns, 12 INT'L REV. FIN. ANALYSIS 3, 10 (2003) (demonstrating stock markets' responses to the announcement of an IMF bailout).

${ }^{226}$ An IMF bailout loan might have a lower interest rate and longer-term maturities, for example, than the debt paid with the proceeds of the loan. 
its long-term ability to service debts; and a decrease in the debt burden would free financial resources for things like structural reforms. ${ }^{227}$

Despite its potential benefits, any IMF bailout of U.S. debt would not be problem-free. ${ }^{228}$ For example, it likely would further increase the risk of moral hazard; if the IMF helps to defray U.S. debt, virtually all IMF member nations might expect IMF protection against default, reducing their incentives to make prudent economic decisions. ${ }^{229}$ In the same vein, creditors who anticipate such protection will have more incentive to take unwarranted financial risks when lending to IMF member nations. ${ }^{230}$ Austerity measures can also backfire. ${ }^{231}$ Recently, the IMF admitted it made mistakes when imposing conditionality on Greece, both underestimating the costs and not foreseeing the harm to the Greek economy of its austerity measures. ${ }^{232}$

\section{CONCLUSION}

It is unlikely, at least in the foreseeable future, that the United States will default on its national debt due to insolvency, but its "rollover risk" - the risk that the government will become temporarily illiquid and unable to borrow sufficient funds to repay its debt-is real. The U.S. government's heavy reliance on short-term, frequently maturing debt aggravates the problem, as does the ongoing political dispute over the federal debt ceiling, which limits the amount of new debt that can be issued to repay maturing debt. Yet the harm caused by a U.S. debt default, even if the default is temporary, could be devastating. It would raise government borrowing costs, not only for the United States but for nations worldwide. It would almost certainly have severe systemic consequences, causing financial markets to plummet and credit markets to freeze, and in turn making it difficult for companies to borrow.

Such a default would also likely attract numerous lawsuits, raising legal issues of first impression. The Fourteenth Amendment to the U.S. Con-

${ }^{227}$ See Judit Kiss, Debt Management in Eastern Europe, E. EUR. ECON., May-June 1994, at 52, 68 (explaining that rescheduling debt payments "gives the debtor some breathing space, time for economic recovery and for boosting economic growth and investment in order to strengthen the country's future debt-servicing capability").

${ }^{228}$ See, e.g., Johnson \& Young, supra note 125, at 120 (suggesting that if the federal government were ever to bail out any of the states it might require certain concessions or affect the longterm economic independence of the states); Idiot's Guide, supra note 203, at 1194 (explaining the problem of moral hazard); Sovereign Debt Restructuring Options, supra note 203, at 97 (same).

${ }^{229}$ Sovereign Debt Restructuring Options, supra note 203, at 97 (explaining that moral hazard occurs when in anticipation of a bailout, states lose the incentive to mitigate their own risk taking).

${ }^{230}$ Idiot's Guide, supra note 203, at 1194.

${ }^{231}$ Matina Stevis \& Ian Talley, IMF Concedes It Made Mistakes on Greece, WALL. ST. J., June 6, 2013, at A11 (explaining that the IMF underestimated the damage that austerity measures would do to Greece's economy).

${ }^{232} I d$. 
stitution, for example, makes it illegal for the federal government to renege on its debt. If the government lacks money to pay the debt on a timely basis, would the default be unconstitutional? Creditors challenging a U.S. debt default would also face several complex procedural legal hurdles, including the need to overcome sovereign immunity, to establish a compensable remedy, and to enforce any resulting judgment against government assets in the face of executive branch opposition.

Given the consequences of default, the government should focus more on the goal of managing its rollover risk. Ironically, the primary goal of U.S. debt issuance traditionally has been minimizing the cost of debt issuance; but that goal motivates the increasing use of short-term debt, which in turn increases rollover risk. The government must try to balance these conflicting goals.

The government should also examine how it could address defaults that otherwise would result from rollover risk. As this Article has shown, it has considerable, though not unlimited, flexibility to do that, including by "monetizing” its debt and printing money to pay maturing debt. But these responses could be costly, at the very least sparking inflation. Moreover, the government's flexibility to print money to avoid default could change in the future if the dollar loses its role as the international reserve currency.

Rollover risk could also be managed by restructuring debt prior to actual default. But bilateral debt restructuring, with the consent of both the government and its creditors, might not always be feasible in time to avoid default; whereas a unilateral debt restructuring would be tantamount to a default because creditors would not be paid on a timely basis according to their original contract terms. A bailout is also unlikely. Only the IMF might have the economic wherewithal to bail out the United States; but even if otherwise feasible, an IMF bailout might not be politically acceptable if (as almost certainly would be the case) it is conditioned on IMF-imposed austerity measures.

Bottom line: there is no magic bullet to put an end to rollover risk. Realistic self-imposed measures of governmental austerity, as well as controls on the issuance of new short-term debt, will likely be needed. As a prominent (and savvy) bankruptcy expert has observed:

The lesson for the United States is at once blindingly obvious and one that none of us wants to hear. Either revenue (taxes) must continue to grow or the cost of government services and benefits, and other national financial commitments, must be reduced .... Find- 
ing clever ways to address the nation's existing public debt simply
will not solve the problem. ${ }^{233}$

The critical question is whether the United States has the political will and integrity to better manage its debt and rollover risk, before it defaults. ${ }^{234}$ The world is waiting for the answer. ${ }^{235}$

${ }^{233}$ Bernstein, supra note 122, at 243.

${ }^{234}$ There is some evidence that the U.S. Treasury is currently intent on issuing debt with longer maturities, although its rationale appears to be to lock in historically low interest rates rather than to control rollover risk. See Jeffrey Sparshott, U.S. Treasury Considers Ways to Extend Debt Maturity, Wall St. J. Blogs (Feb. 6, 2013, 1:13 PM), http://blogs.wsj.com/economics/ 2013/02/06/u-s-treasury-considers-ways-to-extend-debt-maturity/, archived at http://perma.cc/W2 KV-SBJF. Given that rationale, the U.S. Treasury would presumably go back to issuing more short-term debt once interest rates return to normal levels. See id. (explaining that "[l]onger maturities fit with Treasury's efforts to lock in interest rates at historically low levels").

${ }^{235}$ See, e.g., Belton et al., supra note 18, at 1 (observing that "the foreign investor community ... holds nearly half of all [U.S.] Treasury securities”); David Gordon Smith, The World from Berlin: The US Is Holding the Whole World Hostage, SPIEGEL ONLINE (July 15, 2011, 1:54 PM), http://www. spiegel.de/international/world/the-world-from-berlin-the-us-is-holding-the-whole-world-hostage-a774666-druck.html, archived at http://perma.cc/T79J-VYYF ("Nobody can imagine what the repercussions might be if the unthinkable happens and the US [sic] is suddenly no longer a safe haven for investors. Anything is possible, from a small, barely perceptible amount of turbulence in the financial markets to a global panic.”). 
